Biogeosciences Discuss., 7, 1201-1232, 2010 www.biogeosciences-discuss.net/7/1201/2010/ (C) Author(s) 2010. This work is distributed under Biogeosciences the Creative Commons Attribution 3.0 License.

This discussion paper is/has been under review for the journal Biogeosciences (BG). Please refer to the corresponding final paper in BG if available.

\title{
Estimation of nighttime ecosystem respiration over a paddy field in China
}

\section{S. Hossen ${ }^{1}$, T. Hiyama ${ }^{2}$, and H. Tanaka ${ }^{2}$}

${ }^{1}$ Graduate School of Environmental Studies, Nagoya University, Nagoya 464-8601, Japan

${ }^{2}$ Hydrospheric Atmospheric Research Center (HyARC), Nagoya University, Nagoya 464-8601, Japan

Received: 5 February 2010 - Accepted: 11 February 2010 - Published: 17 February 2010

Correspondence to: M. S. Hossen (hossen11@gmail.com)

Published by Copernicus Publications on behalf of the European Geosciences Union.
Estimation of nighttime ecosystem respiration

M. S. Hossen et al.

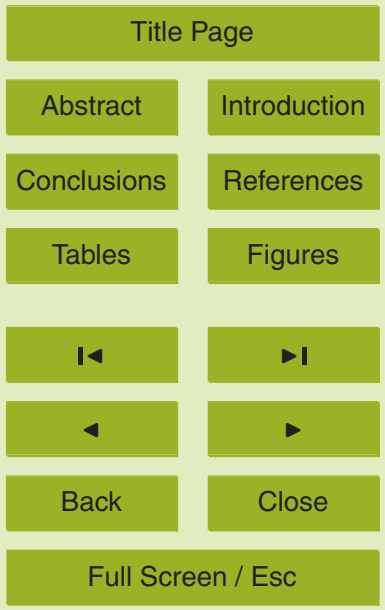

Printer-friendly Version

Interactive Discussion 


\section{Abstract}

Accurate estimation of terrestrial ecosystem respiration is crucial for developing regional- to global-scale carbon budget databases. This study evaluated nighttime ecosystem respiration under low turbulence conditions at a paddy field in China during 5 the 2004 growing season. Data from turbulent flux with storage change and alternatively from $\mathrm{CO}_{2}$ concentration profiles measured from the surface to $32 \mathrm{~m}$ height were investigated and compared. Conditions were separated into windy and calm using a friction velocity $\left(u_{*}\right)$ threshold. On calm nights, the vertical gradient of $\mathrm{CO}_{2}$ concentration was higher near the canopy level and decreased with height. No differences were detected in terms of quantity and seasonality between the eddy covariance-observed nighttime ecosystem respiration $\left(R_{\mathrm{e}}\right)$ and the alternatively calculated $R_{\mathrm{e}}$ under calm conditions. Nighttime underestimation of paddy ecosystem respiration was low, even under calm conditions. Under stable atmospheric conditions, nighttime "loss" of $\mathrm{CO}_{2}$ flux may result mainly from $\mathrm{CO}_{2}$ being stored in air below the sensor height, and ${ }_{15} \mathrm{CO}_{2}$ drainage loss could be small because advection is small. Because the addition of measurement-height storage change is preferable for reducing nighttime underestimation, $u_{*}$ filtering and low turbulence data elimination are not required for the paddy ecosystem. Alternatively, under low turbulence conditions, nighttime flux can be calculated from concentration profiles, but actual measurement of the nocturnal boundary layer height is very important. For gap-filling of nighttime $\mathrm{CO}_{2}$ flux data for a paddy ecosystem, development of multiple regression functions based on the crop biomass/leaf area index in association with field water status is preferable to a single regression function using air/soil temperature.

\section{Introduction}

25 Carbon dioxide emission from both vegetation and soil, known as ecosystem respiration, is an important component of the terrestrial carbon budget. Ecosystem respiration
BGD

7, 1201-1232, 2010

Estimation of nighttime ecosystem respiration

M. S. Hossen et al.

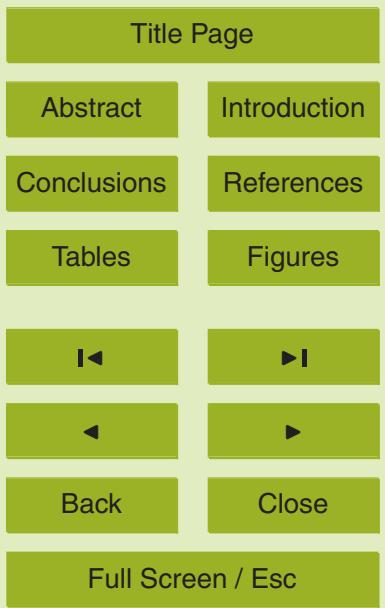

Printer-friendly Version

Interactive Discussion 
acts as a determining factor for ecosystem status as either a carbon source or a carbon sink (e.g., Valentini et al., 2000; Janssens et al., 2001). To precisely estimate annual balances of greenhouse gases, we must understand the source and sink strengths of individual ecosystems and anthropogenic emissions. Climate change is one of the 5 biggest challenges facing humanity. If carbon emission and/or photosynthetic carbon uptake can be manipulated, it may be possible to maintain carbon storage in the terrestrial biome. To effectively manipulate respiratory carbon emission from terrestrial ecosystems, accurate measurements of ecosystem respiration and its major controlling factors are required.

10 Net ecosystem exchange (NEE) is the difference between two large terms: the sequestration of carbon by photosynthesis and the emission of carbon by soil respiration. A delicate balance exists between these terms, and thus even small errors in the estimation of either may lead to relatively large errors in estimated NEE. The eddy covariance (EC) technique is the only reliable method for measuring the net exchange of carbon, water, and energy between a terrestrial ecosystem and the atmosphere over timescales of hours to years. Over the past decade, the number of flux measurement sites using the EC technique to measure surface-atmosphere exchange of carbon, water, and energy fluxes has increased dramatically worldwide (e.g., Baldocchi et al., 2001) and is still expanding.

However, EC measurement difficulties have often been reported under calm nighttime conditions (e.g., Goulden et al., 1996; Staebler and Fitzjarrald, 2004). In the EC approach, net vertical turbulent $\mathrm{CO}_{2}$ flux is measured between the atmosphere and surface (vegetation and soil). Under calm conditions at night, stably stratified atmosphere (negative buoyancy) often occurs, whereby cool, dense air near the surface resists mixing with air above. This decoupling of the atmosphere means that fluxes measured at sensors may be unrepresentative of fluxes from the soil and canopy.

One commonly used approach to limit such nighttime underestimation is addition to the eddy $\mathrm{CO}_{2}$ flux, a term that accounts for the $\mathrm{CO}_{2}$ storage in the layer between the ground and the measurement height (e.g., Wofsy et al., 1993). Another approach is
BGD

7, 1201-1232, 2010

\section{Estimation of nighttime ecosystem respiration}

M. S. Hossen et al.

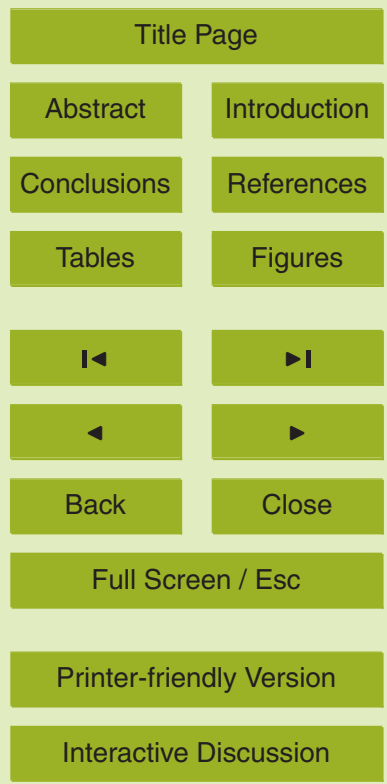


to discard NEE measurements under calm conditions and replace the missing values with NEE modeled as a function of temperature parameterized with measurements under windy conditions (e.g., Goulden et al., 1996; Aubinet et al., 2001; Massman and Lee, 2002). Discrimination between calm and windy conditions is usually based 5 on friction velocity, $u_{*}$, and therefore this approach is often referred to as " $u_{*}$ correction." Some alternative approaches have also been developed for nighttime respiration measurements. One such approach is to derive ecosystem respiration from daytime eddy covariance data by extrapolating the relationship between daytime NEE and solar radiation to zero irradiance; however, uncertainty still remains and the estimated quan10 tity is usually lower (up to $20 \%$ lower) and less responsive to temperature changes (e.g., Kowalski et al., 2003; Xu and Baldocchi, 2004). Closed-chamber techniques are another common approach for measuring $\mathrm{CO}_{2}$ fluxes between the atmosphere and biosphere (e.g., Angell et al., 2001; Arnone and Obrist, 2003; Patrick et al., 2007), but recent studies have shown that the closed-chamber method overestimates $\mathrm{CO}_{2}$ respiration under low turbulence conditions (e.g., Schneider et al., 2009).

A novel approach for nighttime ecosystem respiration developed by van Gorsel et al. $(2007,2008,2009)$ is based on the assumption that advection is small relative to the vertical turbulent flux (Ec) and storage change (Sc) of $\mathrm{CO}_{2}$ in the few hours after sundown. The sum of Ec and Sc reach a maximum during this period, which is used to derive a temperature-response function for ecosystem respiration (van Gorsel et al., 2007). The reliability of the method was established using data from different sites (van Gorsel et al., 2009). However all the sites were forest sites, and thus different results might be expected for short canopy vegetation such as agricultural fields and grassland. Pattey et al. (2002) introduced the nocturnal boundary layer (NBL) method 25 as an alternative under light wind conditions to estimate nighttime $\mathrm{CO}_{2}$ fluxes along with EC fluxes for agricultural crops. Defining the height of the NBL is not always easy due to the occasional presence of temperature and $\mathrm{CO}_{2}$ stratifications. In addition, NBL profiles integrate a larger area than EC due to the variation of the flux footprint. The dimension and orientation of the flux footprint depends largely on the sensor height,

BGD

7, 1201-1232, 2010

\section{Estimation of nighttime ecosystem respiration}

M. S. Hossen et al.

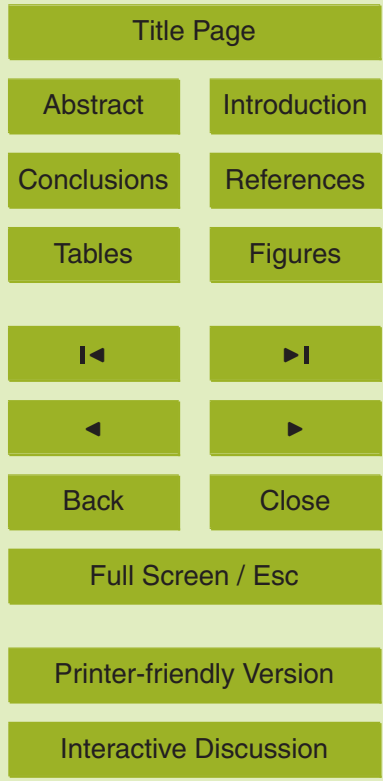


surface roughness, wind speed and direction, and atmospheric stability. Thus, how tall a profile tower is required and how calm-condition data will be evaluated are still research issues for carbon budget studies over short canopy vegetation.

In monsoon Asia, paddy rice is the dominant agricultural crop and an ecosystem that 5 is highly controlled by human activities. For a complete carbon scenario of the Asian region, measurement of the carbon budget in agricultural fields, especially paddy fields, is essential. Previous studies on paddy ecosystems have been generally limited to short-term or seasonal $\mathrm{CO}_{2}$ flux exchange estimation (e.g., Miyata et al., 2000; Saito et al., 2005). Some studies have estimated paddy soil respiration during growth or fal10 low periods using the closed-chamber method (Lou et al., 2004; Zhu et al., 2005) and derived models from fallow period respiration for growing season respiration using the EC method (e.g., Ren et al., 2007). In the growing season, characteristic changes in crop phenology, the vegetation index, and soil water coverage have large influences on the magnitude of ecosystem respiration. Paddy ecosystem respiration is also manipulated through management practices such as irrigation and drainage, and therefore, the magnitude and seasonality of paddy respiration differ from those of other ecosystems.

The study addressed the following questions regarding ecosystem respiration measurement for a rice paddy ecosystem:

1. To what extent is nighttime ecosystem respiration underestimated by EC measurement under low turbulence conditions?

2. How much of the "lost" EC-measured nighttime ecosystem respiration can be retrieved by the storage-change approach?

3. What is the feasibility of using high towers for nighttime ecosystem respiration measurement?

4. How different are EC-measured nighttime NEE and high tower-measured nighttime NEE estimated from storage change?

BGD

$7,1201-1232,2010$

\section{Estimation of nighttime ecosystem respiration}

M. S. Hossen et al.

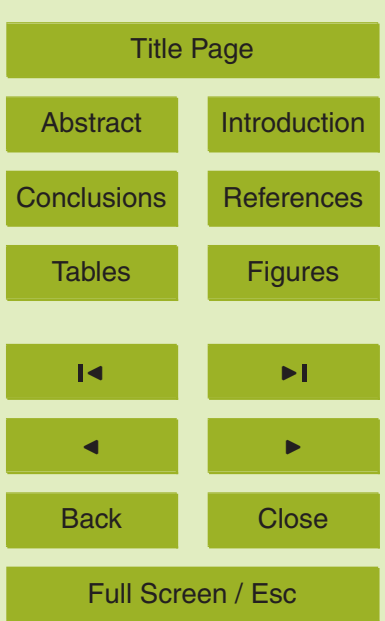

Printer-friendly Version

Interactive Discussion

5. What is the best strategy for gap-filling nighttime data? 


\section{Methodology}

\subsection{Site description}

The monitoring site was located in a transition area between humid and dry regions in China. The annual mean temperature in 2004 was $16.8^{\circ} \mathrm{C}$, ranging from $-7.6^{\circ} \mathrm{C}$ in 5 December to $36.8^{\circ} \mathrm{C}$ in July. Annual precipitation in 2004 was about $1400 \mathrm{~mm}$ (Yatagi et al., 2009), most of which fell from mid-May to mid-October. The cropping pattern was wheat-rice-fallow, following the typical local practice in central China. Wheat was seeded around mid-December and harvested at the end of May. Rice seedlings were planted in mid-June and harvested at the end of September.

This study was conducted at a flat, homogenous paddy field in Shouxian $\left(32.55^{\circ} \mathrm{N}\right.$ and $116.78^{\circ} \mathrm{E}, 22.7 \mathrm{~m}$ a.s.I.) in 2004 . The site was located within the Huai River basin in Anhui Province (Fig. 1), at the southern edge of residential Shouxian, about $2 \mathrm{~km}$ south of the city center. Surrounding land was mainly agricultural fields, with some residences and small buildings that were often surrounded by trees. A paved road 15 passed $200 \mathrm{~m}$ west of the site, and an irrigation canal was located $2 \mathrm{~km}$ west of the road. Lake Wabuhu was $7 \mathrm{~km}$ to the southeast, and the Huai River was $9 \mathrm{~km}$ to the northwest.

An observation tower was established at the southeast corner of a field that included a meteorology station, ponds, and an office building. Paddy fields were distributed northeast to southwest of the tower.

\subsection{Observation items}

Turbulent fluxes were measured at three different heights above the ground surface. Flux densities of $\mathrm{CO}_{2}$, sensible heat, latent heat, and momentum were measured by the EC method. Three components of wind velocity and temperature fluctuation were measured with a sonic anemometer (C-SAT-R3-50; Gill Instruments, Lymington, UK), while the densities of $\mathrm{CO}_{2}$ and water vapor were measured with an open-path infrared
BGD

$7,1201-1232,2010$

Estimation of nighttime ecosystem respiration

M. S. Hossen et al.

\section{Title Page}

Abstract Introduction

Conclusions

Tables References

Figures

14

$\rightarrow$

4

Back

Close

Full Screen / Esc

Printer-friendly Version

Interactive Discussion 
gas analyzer (LI-7500; LI-COR, Lincoln, NE, USA). The sensor heads of the sonic anemometer and the gas analyzer were mounted on the 32-m-tall tower at 3.5, 12.2, and $32 \mathrm{~m}$ above the ground. The physical path length of the sonic anemometer was $0.1 \mathrm{~m}$, and that of the open-path gas analyzer was $0.125 \mathrm{~m}$. The horizontal distance 5 between the two sensor heads was $0.2 \mathrm{~m}$. The data from these sensors were sampled at $10 \mathrm{~Hz}$ using a CR 1000 data logger (CR1000; Campbell Scientific, Logan, UT, USA) and retrieved using a compact flash card. Half-hourly flux densities of $\mathrm{CO}_{2}$, latent heat, and sensible heat were calculated from the covariance between the vertical wind velocity, $w$, and the respective quantities. Air-density fluctuation effects on the mea10 surement of $\mathrm{CO}_{2}$ and latent heat fluxes were corrected following the method of Webb et al. (1980).

Mean temperature and relative humidity were measured with temperature-humidity sensors (HMP-45D; Vaisala, Vantaa, Finland) at five heights: 1.5, 2.8, 10.8, 20.7, and $30.7 \mathrm{~m}$. A pressure sensor (PTB-210; Vaisala) measured atmospheric pressure. Soil 15 temperature was measured with thermocouples at depths of $0.05,0.1,0.2$, and $0.4 \mathrm{~m}$ below the ground surface. Soil heat flux plates (CPR-PHF-01; Climatec, Japan) were set in three places in the soil surface of grassland areas adjacent to the paddy field to measure soil heat flux.

Downward and upward radiation flux densities (both of shortwave and longwave) 20 were measured with a four-component net radiometer (CNR1; Kipp \& Zonen BV, Delft, The Netherlands) mounted on the meteorological tower at a height of $31.8 \mathrm{~m}$. The volumetric water contents of three soil layers $(-0.1,-0.2$, and $-0.4 \mathrm{~m})$ were measured with time-domain reflectometry (TDR) soil moisture sensors (C-CS616-30; Campbell Scientific). These supporting data were sampled every $5 \mathrm{~s}$ using data loggers (CR23X; tional details of the observation have been reported by Tanaka et al. (2007).

BGD

$7,1201-1232,2010$

\section{Estimation of nighttime ecosystem respiration}

M. S. Hossen et al.

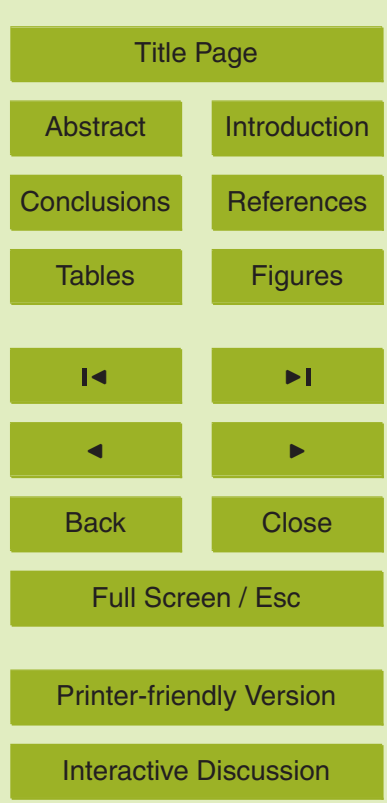




\section{$2.3 \mathrm{CO}_{2}$ budget equation and $\mathrm{EC}$ method}

The carbon dioxide mass conservation equation states that the $\mathrm{CO}_{2}$ produced or absorbed by a biological source/sink is either stored in the air or removed by flux divergence in all directions. This equation has been developed and discussed in detail by

5 various authors, notably Finnigan (1999, 2003), Finnigan et al. (2003), and Feigenwinter et al. (2004). The general equation for NEE calculation is

$$
\mathrm{NEE}=\int_{0}^{z} \frac{\partial C}{\partial t} d z+\overline{w^{\prime} C^{\prime}}(z)+\int_{0}^{z} \bar{w} \frac{\partial C}{\partial z} d z+\int_{0}^{z}\left(\bar{u} \frac{\partial C}{\partial x}+\bar{v} \frac{\partial C}{\partial y}\right) d z,
$$

where term I is storage change (Sc), term II is turbulent transfer (Ec), term III is vertical advection, and term IV is horizontal advection. For a homogenous surface like our site, terms of III and IV are neglected and NEE is measured based on Ec and Sc measurements (Aubinet et al., 2005). Therefore, we calculated NEE as follows:

$$
\begin{aligned}
\mathrm{NEE}_{\mathrm{Ec}} & =\mathrm{Sc}_{1}+\mathrm{Ec}_{1} \\
\mathrm{Sc}_{1} & =\frac{\Delta C_{1}}{\Delta t} \times z_{1} \\
\mathrm{Ec}_{1} & =\frac{w_{1}^{\prime} c_{1}^{\prime}}{}
\end{aligned}
$$

15 where $\mathrm{NEE}_{\mathrm{Ec}}$ is the eddy covariance measurement of $\mathrm{NEE} ; \mathrm{Ec}_{1}$ and $\mathrm{Sc}_{1}$ represent the turbulent flux and storage change at $3.5 \mathrm{~m}$, respectively; $z_{1}$ is the $3.5 \mathrm{~m}$ height; $\Delta C_{1}$ is the change of $\mathrm{CO}_{2}$ density during the duration of focus; and $\Delta t$ is the time difference (30 min).

\subsection{Storage-change method}

20 Changes in $\mathrm{CO}_{2}$ storage (Sc) in the air layer from the surface to $32 \mathrm{~m}$ height were estimated. We calculated the rate of storage change in $\mathrm{CO}_{2}$ densities under calm conditions when turbulent fluxes are thought typically underestimated by the EC approach.

\section{BGD}

$7,1201-1232,2010$

Estimation of nighttime ecosystem respiration

M. S. Hossen et al.

Title Page

Abstract Introduction

Conclusions References

Tables Figures

14 $\rightarrow 1$

4

Back

Close

Full Screen / Esc

Printer-friendly Version

Interactive Discussion 
Total storage change was calculated from the integration of storage changes at three height levels, as follows:

BGD

$$
\begin{aligned}
\mathrm{NEE}_{\mathrm{Sc}} & =\mathrm{Sc}_{1}+\mathrm{Sc}_{2}+\mathrm{Sc}_{3} \\
& =\frac{\Delta C_{1}}{\Delta t} \times\left(z_{1}-0\right)+\frac{\Delta C_{2}}{\Delta t} \times\left(z_{2}-z_{1}\right)+\frac{\Delta C_{3}}{\Delta t} \times\left(z_{3}-z_{2}\right),
\end{aligned}
$$

5 where $\mathrm{NEE}_{\mathrm{Sc}}$ is the storage-change measurement of $\mathrm{NEE}, \mathrm{Sc}_{1}$ is the storage change between the surface to $3.5 \mathrm{~m}$ height, $\mathrm{Sc}_{2}$ is that between 3.5 to $12.2 \mathrm{~m}$ height, and $\mathrm{Sc}_{3}$ is that between 12.2 to $32 \mathrm{~m}$ height. $\Delta C_{1}, \Delta C_{2}$, and $\Delta C_{3}$ are the changes in $\mathrm{CO}_{2}$ density during the focus duration times at $3.5,12.2$, and $32 \mathrm{~m}$ height, respectively, and $z_{1}, z_{2}$, and $z_{3}$ are the measurement heights of $3.5 \mathrm{~m}, 12.2 \mathrm{~m}$, and $32 \mathrm{~m}$, respectively.

$10 \Delta t$ is the time difference $(30 \mathrm{~min})$.

\subsection{Data processing}

Missing data due to instrument malfunction are a common problem at tower flux sites. Unfavorable conditions may also cause specious flux data.

\subsubsection{Determination of the $u_{*}$ threshold}

15 For nighttime $\mathrm{CO}_{2}$ flux data correction, the most important aspect for most research is determining the $u_{*}$ threshold, taking the quality and quantity of effective data into account. We chose the average value test (AVT) method for determining the $u_{*}$ threshold, as described in the ChinaFlux methodology (Zhu et al., 2006).

\subsubsection{Establishment of the model}

20 When analyzing ecosystem respiration with data measured by the EC method, previous studies have used flux data from nighttime periods to establish the relationship between ecosystem and environmental factors (e.g., Baldocchi et al., 2001; Saito et al., 2005). Because respiration at nighttime during the growing season includes plant 1209
$7,1201-1232,2010$

Estimation of nighttime ecosystem respiration

M. S. Hossen et al.

Title Page

Abstract

Introduction

Conclusions

References

Tables

Figures

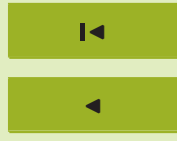

$\rightarrow 1$

Back

Close

Full Screen / Esc

Printer-friendly Version

Interactive Discussion 
respiration, soil respiration, and respiration produced by root exudates, we used surface albedo to separate periods to establish the model. Air temperature and data that passed all quality-control criteria were used to derive the regression function. We used the following simple exponential function:

$5 \quad R_{\mathrm{e}}=a \exp (b T)$,

where $a$ and $b$ are empirical constants to be determined by regression; $T$ is air temperature; $b$ is related to a temperature coefficient $Q_{10}$, as $b=\ln \left(Q_{10}\right) / 10$; and a indicates $R_{\mathrm{e}}$ at $0^{\circ} \mathrm{C}$. In this study, we divided the whole study duration into four periods (early vegetative, mid-vegetative, full vegetative, and mature) and determined $a$ and $b$ for the 10 respective periods by fitting the nocturnal NEE as a function of average air temperature.

\subsubsection{General flow for processing nighttime $\mathrm{CO}_{2}$ flux}

Figure 2 presents a flowchart of the nighttime $\mathrm{CO}_{2}$ flux data processing. If the atmospheric condition was unstable, $\mathrm{CO}_{2}$ diffused from plants and soil could reach the sensor height. The flux value (Ec) when $u_{*}>0.1 \mathrm{~ms}^{-1}$ could be considered a real value 15 and $\mathrm{NEE}_{\mathrm{Ec}}$ was taken as the sum of $\mathrm{Ec}_{1}$ and $\mathrm{Sc}_{1}$. Under the stable atmospheric condition when $u_{*}<0.1 \mathrm{~ms}^{-1}$, the temporal change in $\mathrm{CO}_{2}$ storage could be considered as the alternate value; thus, $\mathrm{NEE}_{\mathrm{Sc}}$ was taken as the value. Data were rejected if they were collected under unfavorable conditions such as rainfall, wind direction from a contaminated area other than the target area, high wind speed (WS $>10 \mathrm{~ms}^{-1}$ ), or highly turbulent conditions $\left(\sigma_{w}>0.5 \mathrm{~ms}^{-1}\right)$. Some faulty data due to unstable conditions of $\mathrm{CO}_{2}$ densities, $u_{*}$, and wind direction were used to discard additional data based on a coefficient of variation $(\mathrm{CV})$ threshold. Finally, considering the lower and upper limits ( 0 and $15 \mu \mathrm{mol} \mathrm{m} \mathrm{m}^{-2} \mathrm{~s}^{-1}$, respectively) of effective nighttime NEE, other faulty data were rejected. The effective nighttime NEE threshold value was determined on the basis of experience and examination of observed data. Zhu et al. (2006) also used 0 as the lower limit in their study. A model was established using the effective data, meteorological data including air temperature $(T)$, and a biomass index. Finally, all missing
BGD

$7,1201-1232,2010$

Estimation of nighttime ecosystem respiration

M. S. Hossen et al.

Title Page

Abstract

Introduction

Conclusions

Tables

References

Figures

14

$\rightarrow$

4

Back

Close

Full Screen / Esc

Printer-friendly Version

Interactive Discussion 
data were replaced with model data. Solar radiation was used to separate daytime and nighttime. For the comparisons of data, $u_{*}$ filtering was not performed, but all other steps of data processing were carried out and considered to be the general data processing procedure.

\section{$5 \quad 3$ Results}

\subsection{Meteorology and surface conditions}

Figure 3 presents time series of daily precipitation, air temperature, and volumetric soil water content at depths of $0-0.4 \mathrm{~m}$ during the rice growing period in 2004 . Annual precipitation was $1400 \mathrm{~mm}$ and most precipitation occurred during the rice growing sea-

son (June-September). Soil water content measured at the nearby grassland showed a relatively normal range $(0.40-0.45)$ with distinctly higher values and saturation in the early to middle vegetation stages (up to day of year (DOY) 205); thereafter, soil water decreased slightly but then became stable for the rest of the period. Air temperature was around $25^{\circ} \mathrm{C}$ at the beginning of rice growth and began to gradually decrease from DOY 218. At the end of the growing season (DOY 280), the air temperature was around $15^{\circ} \mathrm{C}$.

Figure 4 shows surface conditions during the growing period, illustrating the characteristic patterns of sensible heat flux $(H)$, latent heat flux (LE), daytime $\mathrm{CO}_{2}$ flux, and albedo. At the beginning of the growing season, $H$ was around $100 \mathrm{~W} \mathrm{~m}^{-2}$ similar to LE. While $H$ was approximately $50 \mathrm{~W} \mathrm{~m}^{-2}$ for the entire growing period, $H$ became dominant after DOY 270. LE was large throughout the growing period, showing an opposite pattern compared to $\mathrm{H}$. Daytime $\mathrm{CO}_{2}$ flux indicated a gradual increase in $\mathrm{CO}_{2}$ uptake with plant growth, reaching the highest value during maximum canopy coverage (DOY 210) and then gradually decreasing until harvest, when daytime $\mathrm{CO}_{2}$ flux carbon

suddenly decreased just after harvest (DOY 278). Good synchronization of $H$, LE CO
BGD

7, 1201-1232, 2010

Estimation of nighttime ecosystem respiration

M. S. Hossen et al.

Title Page

Abstract

Introduction

Conclusions

Tables

References

Figures

14

$\rightarrow$

4

Back

Close

\section{Full Screen / Esc}

Printer-friendly Version

Interactive Discussion 
flux, and surface albedo occurred at our site, with minimum $H$, maximum LE, maximum $\mathrm{CO}_{2}$ uptake, and maximum surface albedo in the maximum canopy cover period.

\section{BGD}

\section{2 $\mathrm{CO}_{2}$ concentration and storage change estimation}

Figure 5 illustrates the development of the vertical $\mathrm{CO}_{2}$ concentration gradient below 5 the tower measurement height on windy, intermittent, and calm nights. Under stable atmospheric conditions, $\mathrm{CO}_{2}$ concentrations at 3.5 and $12.2 \mathrm{~m}$ heights gradually increased with time and then gradually decreased prior to sunrise. Near the canopy layer at $3.5 \mathrm{~m}$ height, $\mathrm{CO}_{2}$ densities showed higher concentrations than at 12.2 and $32 \mathrm{~m}$ heights; the difference in $\mathrm{CO}_{2}$ concentration and development of the vertical

$10 \mathrm{CO}_{2}$ concentration gradient were also higher between $3.5 \mathrm{~m}$ and $12.2 \mathrm{~m}$ than between $12.2 \mathrm{~m}$ and $32 \mathrm{~m}$ under low turbulence conditions. The change in $\mathrm{CO}_{2}$ densities at $32 \mathrm{~m}$ height was small except under unstable turbulent conditions. Under turbulent conditions, $\mathrm{CO}_{2}$ densities differed little between heights, with changes in $\mathrm{CO}_{2}$ concentration. The largest changes in $\mathrm{CO}_{2}$ concentration over the calm and intermittent nights were observed close to the lower measurement height $(3.5 \mathrm{~m})$ near the ground during low turbulence. Under calm conditions, a small change in $u_{*}$ led to a $\mathrm{CO}_{2}$ concentration change, while under turbulent conditions, $u_{*}$ had no impact on $\mathrm{CO}_{2}$ concentration change.

\subsection{Nighttime NEE estimation}

20 Nighttime ecosystem exchanges were grouped by turbulent and low turbulence or calm conditions; here we focus on the calm conditions. Figure 6 shows nighttime values of NEE and its subcomponents (eddy flux $\left(\mathrm{Ec}_{1}\right)$ at $3.5 \mathrm{~m}$ and the storage terms at $3.5 \mathrm{~m}$ $\left(\mathrm{Sc}_{1}\right)$ and $\left.32 \mathrm{~m}(\mathrm{Sc})\right)$ as a function of $u_{*}$. The figure shows that under low turbulence conditions, eddy flux was lower than NEE and the storage term was about $7 \%$ of the eddy flux at low measurement height $(3.5 \mathrm{~m})$. The subcomponents exhibit consistent behavior: at low $u_{*}$ conditions (when inversion builds up), some respired $\mathrm{CO}_{2}$ cannot
$7,1201-1232,2010$

Estimation of nighttime ecosystem respiration

M. S. Hossen et al.

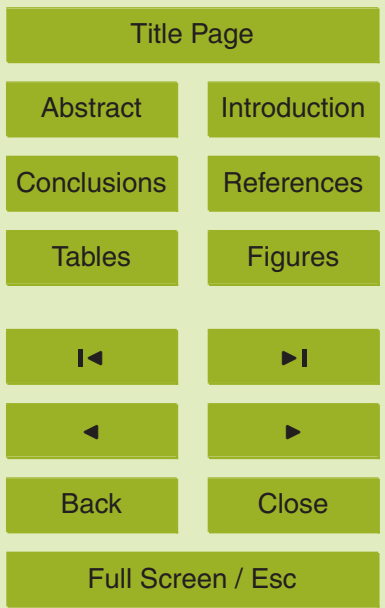

Printer-friendly Version

Interactive Discussion 
reach the eddy level and remains trapped below the $3.5 \mathrm{~m}$ level. This assumes an air layer in which the $\mathrm{CO}_{2}$ concentration is gradually growing, which must appear in the rate of storage change. As nighttime $u_{*}$ increases, eddy flux becomes an increasingly significant term in NEE, while the importance of the storage term decreases. When 5 the storage term is added, "lost" fluxes during nighttime can be retrieved. On the other hand, NEE calculated from the concentration profile from the 32-m tower shows higher values under calmer conditions and becomes stable under windy conditions (Fig. 6). Similar quantities of $\mathrm{NEE}_{\mathrm{Ec}}(2.96 \pm 0.22)$ and $\mathrm{NEE}_{\mathrm{Sc}}(3.05 \pm 0.23)$ were found under calm conditions after performing all quality checks. Moreover, the temperature sensitivities 10 of $\mathrm{NEE}_{\mathrm{Ec}}$ and $\mathrm{NEE}_{\mathrm{Sc}}$ under calm conditions and $\mathrm{NEE}_{\mathrm{Ec}}$ under both windy and calm conditions showed similar magnitude and temperature dependency (Fig. 7). During the growing period, NEE over the paddy fields showed characteristic seasonal change. NEE was low in the early vegetative stage, gradually increased with increasing vegetation cover to reach maximum values during full vegetation coverage, and decreased 15 prior to harvest. The $\mathrm{NEE}_{\mathrm{Ec}}$ under windy conditions, $\mathrm{NEE}_{\mathrm{Sc}}$ under calm conditions, and $\mathrm{NEE}_{\mathrm{Ec}}$ under both conditions exhibited similar seasonality and magnitude (Fig. 8). The seasonality of NEE before and after gap-filling also had similar tendencies except during the full vegetative stage and in day-to-day fluctuation of non-gap-filled NEE in relation to atmospheric and surface conditions.

\subsection{Gap-filling model}

We obtained different exponential regression models depending on the data period. We considered the whole growing period and separation of the growing period based on crop phenology. We also examined $\mathrm{NEE}_{\mathrm{Ec}}$ data for the low turbulence condition and the alternate $\mathrm{NEE}_{\mathrm{Sc}}$ data. The offsets of the exponential regression functions, indicated 25 by parameters $a$ and $b$ and the fitting strength, were evaluated by the coefficient of determination $\left(r^{2}\right)$ (Table 1). The degree of curvature of the regression function indicated by parameter $b$ was larger $(0.0393)$ for $\mathrm{NEE}_{\mathrm{Ec}}$ than for $\mathrm{NEE}_{\mathrm{Sc}}(0.0254)$ and the range of $b$ values changed (0.007-0.05) when separating the growing season based on crop
BGD

$7,1201-1232,2010$

\section{Estimation of nighttime ecosystem respiration}

M. S. Hossen et al.

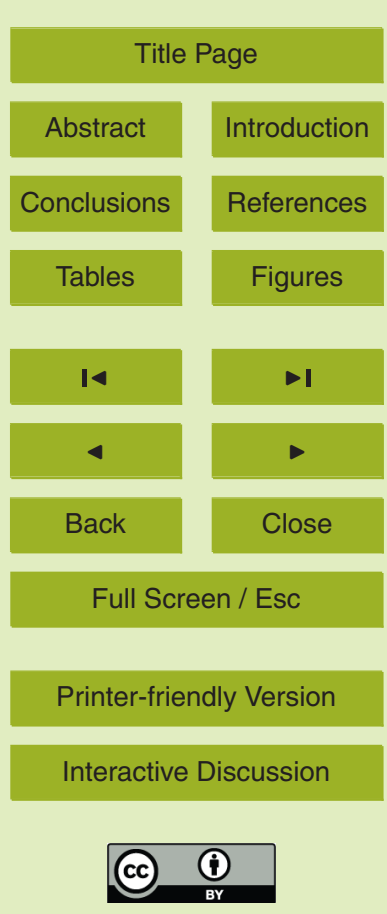


phenology.

The regression function derived from $\mathrm{Ec}_{1}+\mathrm{Sc}_{1}$ was better than that derived from $\mathrm{Sc}$ at low turbulence with $r^{2}$ values of 0.89 and 0.70 , respectively. The temperature coefficient $\left(Q_{10}\right)$, which is an important index of the dependence of air/soil temperature on soil respiration, reflects the effect of change in air/soil temperature on soil respiration. In the paddy ecosystem, $Q_{10}$ values are derived from nighttime air temperature. The value of $Q_{10}$ was higher (1.48) for $\mathrm{NEE}_{\mathrm{Ec}}$ than for the alternate $\mathrm{NEE}_{\mathrm{Sc}}$ data (1.28), but $Q_{10}$ changed to a range of 1.07-1.67 when using exponential factions based on growth periods.

$10 \quad$ Figure 9 presents cumulative nighttime ecosystem respiration over the growing period after gap-filling estimated using the single exponential function and the separated exponential functions. The difference in cumulative nighttime ecosystem respiration between the general and alternative method was negligible when data were gap-filled using the single function. Little difference was observed between the two methods

when using the separated exponential functions, although values were higher in the $\mathrm{NEE}_{\mathrm{Ec}}$ case. However, the results using single and separated exponential functions for gap-filling differed largely. Exponential functions based on periods always produced higher cumulative respiration except during DOY 185-200 (Fig. 9). The difference in single exponential functions and separated exponential functions on cumulative respiration was around $100 \mathrm{~g} \mathrm{C} \mathrm{m}^{-2}$.

\section{Discussion}

We assumed a turbulent flux of zero for the calm condition. Therefore, nighttime NEE could be calculated from the $\mathrm{CO}_{2}$ concentration change measured at three different heights from the surface to $32 \mathrm{~m}$. At night when convective heating ends, the NBL, a shallow, weakly turbulent layer that extends to heights of only tens of meters, is bounded by a low-level radiative inversion. The inversion inhibits vertical mixing so that emissions of gases from the surface are contained in a shallow air layer, where gas

BGD

7, 1201-1232, 2010

Estimation of nighttime ecosystem respiration

M. S. Hossen et al.

Title Page

Abstract

Introduction

Conclusions

Tables

References

Figures

14

4

Back

Close

Full Screen / Esc

Printer-friendly Version

Interactive Discussion 
concentrations change appreciably. When inversion builds up, the eddy flux is close to zero and all $\mathrm{CO}_{2}$ remains trapped below the inversion level. Therefore, the storage change between the ground and the inversion layer will represent true biological emission flux. Similar to Pattey et al. (2002) and Acevedo et al. (2004), this study also 5 showed a good correlation between $\mathrm{NEE}_{\mathrm{Ec}_{\mathrm{c}}}$ and $\mathrm{NE}_{\mathrm{Sc}}$. In short canopy vegetation, storage changes have little influence under a calm condition and no influence under windy conditions. Saito et al. (2005) also concluded that the contribution of storage change is only $6 \%$ under calm conditions and minor under windy conditions for a rice paddy.

10 Stable atmospheric conditions are often associated with decoupling of airflows above and within the plant canopy, leading to the development of advection by drainage flows and causing nighttime underestimation of ecosystem respiration. The underestimation of nighttime NEE is lower in a short canopy such as rice than in a large canopy such as forest because of the lower required measurement height and homogenous 15 surface condition of the former. In short canopy vegetation, the maximum measurement height is usually a few meters, while in forest canopy usually more than $30 \mathrm{~m}$ is required, depending on canopy height. Even under low atmospheric turbulence conditions, measurements at lower heights over a short canopy can detect a large percentage of eddy-containing target molecules, while measurements at higher levels detect smaller percentages of eddy-containing target molecules under the same condition.

van Gorsel et al. (2009) reported that for early evening, forest respiration estimates from micrometeorological data showed a distinct peak and agreed very well with estimates from chamber measurements. Good estimates of NEE were obtained during this time window, while for the remainder of the night, total ecosystem respiration

was largely underestimated compared to chamber measurements because of cold air drainage and associated advection. Advection occurs mainly in the presence of flows associated with topography (drainage flows) or land-cover differences (breezes) (Aubinet, 2008). Paddy fields have flat topography and uniform canopy. In this study, no distinct respiration peak period or underestimation period was detected, demonstrating

\section{BGD}

$7,1201-1232,2010$

\section{Estimation of nighttime ecosystem respiration}

M. S. Hossen et al.

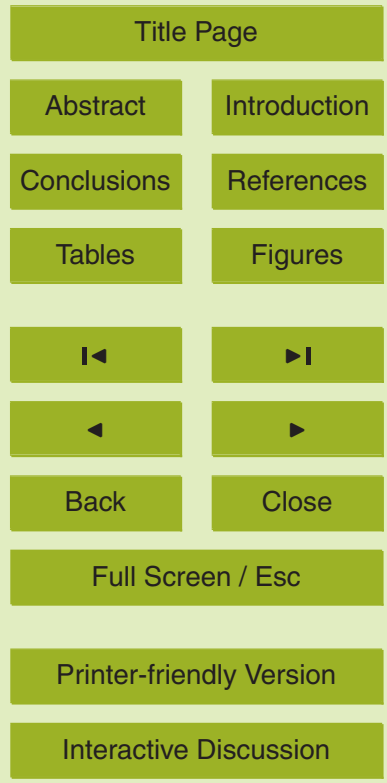


that the influence of advection was negligible.

Although under calm conditions, both methods produced similar average NEE, $\mathrm{NEE}_{\mathrm{Sc}}$ was slightly larger under very calm conditions $\left(u_{*}<0.05\right)$ and slightly lower under calm conditions $\left(u_{*} \leq 0.1\right)$. This difference might have been caused by the NBL 5 height. In this study, we used a fixed 32-m NBL height, which might have led to the higher NEE under the very calm condition and slightly lower NEE under the calm condition.

To group the nighttime ecosystem exchange measurements according to respective ambient wind conditions, a $u_{*}$ threshold of $0.1 \mathrm{~m} \mathrm{~s}^{-1}$ was applied. This value is well 10 within the range of thresholds used in previous EC studies to distinguish between well developed and low turbulence conditions at low canopy study sites. Saito et al. (2005) and Ren et al. (2007) also applied a $0.1 \mathrm{~m} \mathrm{~s}^{-1}$ threshold for screening nighttime $\mathrm{CO}_{2}$ fluxes measured by EC at rice paddy sites. Higher $u_{*}$ thresholds have typically been used for forest sites: $0.17 \mathrm{~m} \mathrm{~s}^{-1}$ (Goulden et al., 1996), and $0.25 \mathrm{~m} \mathrm{~s}^{-1}$ (Law et al., 15 1999; van Gorsel et al., 2007), $0.4 \mathrm{~m} \mathrm{~s}^{-1}$ (Dolman et al., 2004). Massman and Lee's (2002) survey of the literature found that $u_{*}$ thresholds varied from 0.0 to $0.6 \mathrm{~m} \mathrm{~s}^{-1}$ for different sites.

In present study, $Q_{10}$ was smaller than values found at other sites. Zou et al. (2003) and Zhu et al. (2005) measured soil respiration using the closed-chamber method dur20 ing rice-growing periods in a subtropical region of China and reported $Q_{10}$ values for soil of 1.68 and 1.70, respectively. The difference in $Q_{10}$ values might have been due to methodological and site differences, and the chamber method is known to show higher nighttime ecosystem respiration compared to the EC method (Griffis et al., 2004).

Plant biomass in crop fields exhibits large seasonal changes, which consequently 25 affect ecosystem respiration. Several studies have found that respiration in grasslands and field crop ecosystems linearly increases with biomass production (e.g., Pattey et al., 2002; Saito et al., 2005; Shimoda et al., 2009). Thus, crop biomass is an essential factor in a respiration model. Growth respiration dominates in a lower crop biomass condition, while maintenance respiration becomes dominant with a larger crop

BGD

$7,1201-1232,2010$

\section{Estimation of nighttime ecosystem respiration}

M. S. Hossen et al.

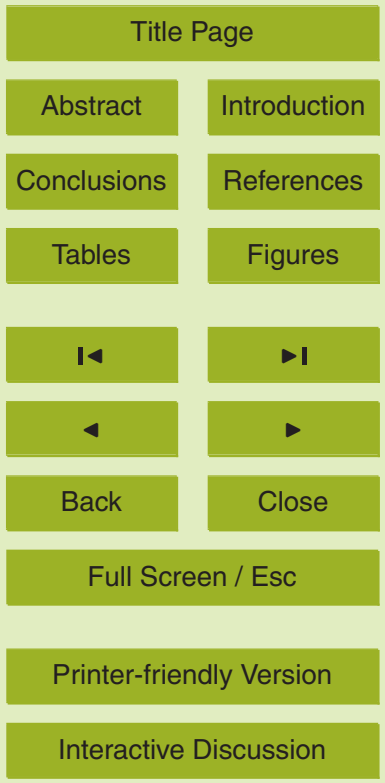

Interactive Discussion 
biomass. Therefore, establishment of a model for nighttime respiration using soil/air temperature and different exponential regression functions with a biomass index is preferable. Similar results were reported by Saito et al. (2005) for paddy rice and Pattey et al. (2002) for soybean fields. A rice paddy ecosystem is controlled by human 5 activities, and thus water management such as irrigation and drainage should be considered in developing the exponential model. Saito et al. (2005) showed the midterm drainage of paddies impacts on ecosystem respiration.

Various $u_{*}$ thresholds have been used for different study sites, biome types, and determination methods. No set limits of $u_{*}$ have been established for specific biomes, 10 and in many cases, the ratio of underestimation by EC measurements was found to be consistent for a wide range of wind speed and $u_{*}$ (van Gorsel et al., 2007). Thus, in short canopy vegetation, $u_{*}$ filtering and low $u_{*}$ data elimination are not necessary, and alternatively, under stable conditions, flux can be calculated by measuring $\mathrm{CO}_{2}$ profiles from high towers.

\section{Conclusions}

Accurate estimation of terrestrial ecosystem respiration is fundamental for developing regional to global carbon budget databases. Many meteorologists, hydrologists, crop physiologists, ecologists, and plant biochemists have focused on this issue. The present study evaluated nighttime ecosystem respiration of paddy fields using the $\mathrm{CO}_{2}$ concentration profile and eddy covariance methods. We described the data treatment procedure and observational results, and conclude with the following insights:

1. In short canopy vegetation like paddy rice, nighttime underestimation of ecosystem respiration is low even under calm conditions.

2. Rice paddies have flat terrain and thus very little influence by the advection term; addition of storage change by measurement height can greatly reduce nighttime
BGD

$7,1201-1232,2010$

\section{Estimation of nighttime ecosystem respiration}

M. S. Hossen et al.

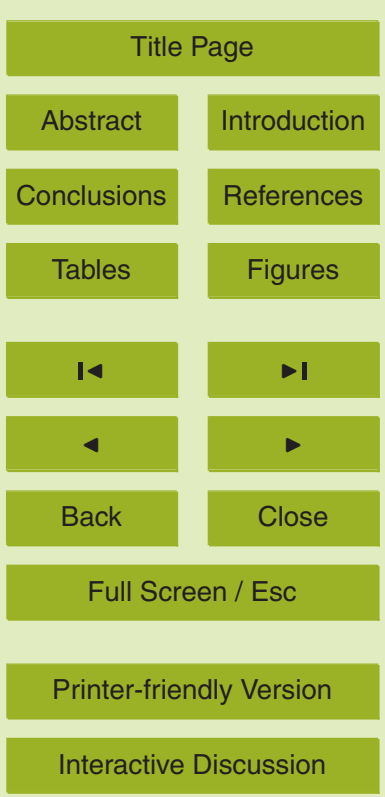


flux underestimation under stable atmospheric conditions. Therefore $u_{*}$ filtering and low turbulence data elimination are not required for this type of ecosystem.

3. Under low turbulence conditions, as an alternative to EC measurement, nighttime flux can be calculated from concentration profiles measured from a high tower, but accurate measurement of NBL height is very important.

4. For gap-filling of nighttime $\mathrm{CO}_{2}$ flux for a rice paddy ecosystem, development of regression functions based on the crop biomass/leaf area index in association with field water status is preferable to using a single regression function based on air/soil temperature.

10 All of the parameters were measured only up to $32 \mathrm{~m}$ height based on a previous research finding that changes in nocturnal wind speed were negligible above $30 \mathrm{~m}$ at this study site. The main limitation of this study is that we could not measure the NBL height. For evaluation of nocturnal ecosystem respiration under stable atmospheric conditions, the best options are measurement of eddy covariance, measurement from a high tower with known NBL height, and the chamber method.

\section{References}

Acevedo, O. C., Moraes, O. L. L., Da Silva, R., Fitzarrald, D. R., Sakai, R. K., Staebler, R. M., and Czikowsky, M. J.: Inferring nocturnal surface fluxes from vertical profiles of scalars in an Amazon pasture, Global Change Biol., 10, 886-894, 2004.

Angell, R. F., Svejcar, T., Bates, J., Saliendra, N. Z., and Johnson, D. A.: Bowen ratio and closed chamber carbon dioxide flux measurements over sagebrush steppe vegetation, Agric. For. Meteorol., 108, 153-161, 2001.

Arnone, J. A. and Obrist, D.: A large daylight geodesic dome for quantification of wholeecosystem $\mathrm{CO}_{2}$ and water vapour fluxes in arid shrublands, J. Arid Environ., 55, 629-643, 252003

Aubinet, M.: Eddy covariance $\mathrm{CO}_{2}$ flux measurements in nocturnal conditions: and analysis of the problem, Ecol. App., 18, 1368-1378, 2008.

\section{Estimation of nighttime ecosystem respiration}

M. S. Hossen et al.

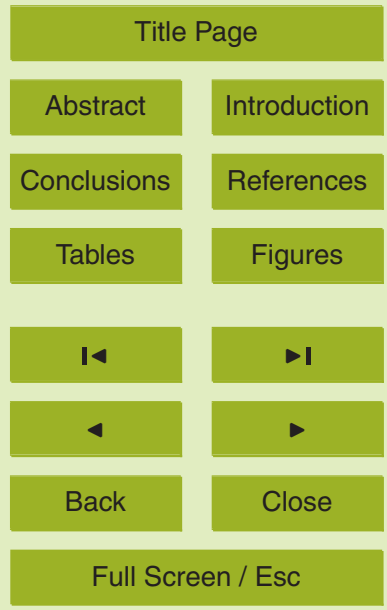

Printer-friendly Version

Interactive Discussion 
Aubinet, M., Berbigier, P., Bernhofer, C. H., Cescatti, A., Feigenwinter, C., Granier, T. H., Nwald, G. R. U., Havrankova, K., Heinesch, B., Longdoz, B., Marcolla, B., Montagnani, L., and Sedlak, P.: Comparing $\mathrm{CO}_{2}$ storage and advection conditions at night at different carboeuroflux sites, Bound.-Lay. Meteorol., 116, 63-94, 2005.

5 Aubinet, M., Chermanne, B., Vandenhaute, M., Longdoz, B., Yernaux, M., and Laitat, E.: Long term carbon dioxide exchange above a mixed forest in the Belgian Ardennes, Agric. For. Meteorol., 108, 293-315, 2001.

Baldocchi, D., Falge, E., Gu, L. H., Olson, R., Hollinger, D., Running, S., Anthoni, P., Bernhofer, C., Davis, K., Evans, R., Fuentes, J., Goldstein, A., Katul, G., Law, B., Lee, X. H., Malhi, Y.,

10 Meyers, T., Munger, W., Oechel, W., Paw, U. K. T., Pilegaard, K., Schmid, H. P., Valentini, R., Verma, S., Vesala, T., Wilson, K., and Wofsy, S.: FLUXNET: A new tool to study the temporal and spatial variability of ecosystem-scale carbon dioxide, water vapor, and energy flux densities, B. Am. Meteorol. Soc., 82, 2415-2434, 2001.

Dolman, A. J., Maximov, T. C., Moors, E. J., Maximov, A. P., Elbers, J. A., Kononov, A. V., 15 Waterloo, M. J., and van der Molen, M. K.: Net ecosystem exchange of carbon dioxide and water of far eastern Siberian Larch (Larix cajanderii) on permafrost, Biogeosci., 1, 133-146, 2004.

Feigenwinter, C., Bernhofer, C., and Vogt, R.: The influence of advection on short term $\mathrm{CO}_{2}$ budget in and above a forest canopy, Bound.-Lay. Meteorol., 113, 201-224, 2004.

20 Finnigan, J.: A comment on the paper by Lee (1998): On micrometeorological observations of surface-air exchange over tall vegetation, Agric. For. Meteorol., 97, 55-64, 1999.

Finnigan, J. J., Clement, R., Malhi, Y., Leuning, R., and Cleugh, H. A.: A re- evaluation of longterm flux measurement techniques. Part I: averaging and coordinate rotation, Bound.-Lay. Meteorol., 107, 1-48, 2003.

Goulden, M. L., Munger, J. W., Fan, S.-M., Daube, B. C., and Wofsy, S. C.: Measurements of carbon sequestration by long-term eddy covariance: methods and a critical evaluation of accuracy, Global Change Biol., 2, 169-182, 1996.

Griffis, T. J., Black, T. A., Gaumont-Guay, D., Drewitt, G. B., Nesic, Z., Barr, A. G., Morgenstern, K., and Kljun, N.: Seasonal variation and partitioning of ecosystem respiration in a southern 30 boreal aspen forest, Agric. For. Meteorol., 125, 207-223, 2004.

Janssens, I. A., Matteucci, H. G., Kowalski, A. S., Buchman, N., Epron, D., Pilegaard, K., Kutsch, W., Longdoz, B., Grunwald, T., Montagnani, L., Dore, S., Rebmann, C., Moors, E. J., Grelle, A., Rannik, U., Morgenstern, K., Oltchev, S., Clement, R., Gudmundsson, J., Minerbi,

BGD

$7,1201-1232,2010$

\section{Estimation of nighttime ecosystem respiration}

M. S. Hossen et al.

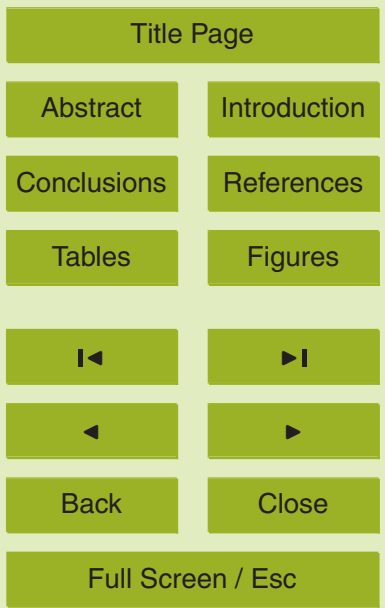

Printer-friendly Version

Interactive Discussion 
S., Berbigier, P., Ibrom, A., Moncrieff, J., Aubinet, M., Bernhofer, C., Jensen, N. O., Vesala, T., Granier, A., Schulze, E. D., Lindroth, A., Dolman, A. J., Jarvis, P. G., Ceulamans, R., and Valentini, R.: Productivity overshadows temperature in determining soil and ecosystem respiration across European forests, Global Change Biol., 7, 269-278, 2001.

5 Kowalski, S., Sartore, M., Burlett, R., Berbigier, P., and Loustau, D.: The annual carbon budget of a French pine forest (Pinus pinaster) following harvest, Global Change Biol., 9, 10511065, 2003.

Law, B. E., Ryan, M. G., and Anthoni, P. M.: Seasonal and annual respiration of a ponderosa pine ecosystem, Global Change Biol., 5, 169-182, 1999.

10 Lou Y. S., Li, Z. P., and Zhang, T. L.: $\mathrm{CO}_{2}$ emission from upland and paddy red soils in midsubtropical China, Acta Ecol. Sin., 24, 978-983, 2004 (in Chinese with English abstract).

Massman, W. J. and Lee, X.: Eddy covariance flux corrections and uncertainties in long-term studies of carbon and energy exchanges, Agric. For. Meteorol., 113, 121-144, 2002.

Miyata, A., Leuning, R., Denmead, O. T., Kim, J., and Harazono, Y.: Carbon dioxide and 15 methane fluxes from an intermittently flooded paddy field, Agric. For. Meteorol., 102, 287303, 2000.

Patrick, L., Cable, J., Potts, D., Ignace, D., Barron-Gafford, G., Griffith, A., Alpert, H., Van Gestel, N., Robertson, T., Huxman, T. E., Zak, J., Loik, M. E., and Tissue, D.: Effects of an increase in summer precipitation on leaf, soil, and ecosystem fluxes of $\mathrm{CO}_{2}$ and $\mathrm{H}_{2} \mathrm{O}$ in a sotol grassland in Big Bend National Park, Texas, Oecologia, 151, 704-718, 2007.

Pattey, E., Strachan, I. B., Desjardins, R. L., and Massheder, J.: Measuring nighttime $\mathrm{CO} 2$ flux over terrestrial ecosystems using eddy covariance and nocturnal boundary layer methods, Agric. For. Meteorol., 113, 145-158, 2002.

Ren, X., Wang, Q., Tong, C., Wu, J., Wang, K., Zhu, Y., Lin, Z., Watanabe, M., and Tang, G.: Estimation of soil respiration in a paddy ecosystem in the subtropical region of China, Chinese Sci. Bull., 52, 2722-2730, 2007.

Saito, M., Miyata, A., Nagai, H., and Yamada, T.: Seasonal variation of carbon dioxide exchange in rice paddy field in Japan, Agric. For. Meteorol., 135, 93-109, 2005.

Schneider, J., Kutzbach, L., Schulz, S., and Wilmking, M.: Overestimation of $\mathrm{CO}_{2}$ respiration fluxes by the closed chamber method in low-turbulence nighttime conditions, J. Geophys. Res., 114, 1-10, 2009.

Shimoda, S., Gilzae, L., Yokoyama, T., Liu, J., Saito, M., and Oikawa, T.: Response of ecosystem $\mathrm{CO}_{2}$ exchange to biomass productivity in a high yield grassland, Environ. Exp. Bot., 65,

BGD

$7,1201-1232,2010$

\section{Estimation of nighttime ecosystem respiration}

M. S. Hossen et al.

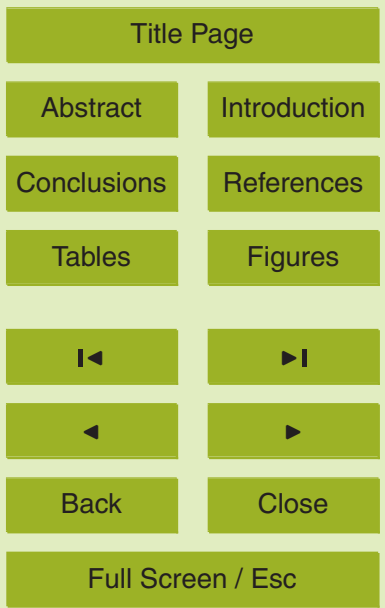

Printer-friendly Version

Interactive Discussion 
425-431, 2009.

Staebler, R. M. and Fitzjarrald, D. R.: Observing subcanopy $\mathrm{CO}_{2}$ advection, Agric. For. Meteorol., 122, 139-156, 2004.

Tanaka, H., Hiyama, T., Yamamoto, K., Fujinami, H., Shinoda, T., Higuchi, A., Endo, S., Ikeda,

$5 \quad$ S., Li, W., and Nakamura, K.: Surface flux and atmospheric boundary layer observations from the LAPS project over the middle stream of the Huaihe river basin in China, Hydrol. Processes, 21, 1997-2008, 2007.

Valentini, R., Matteucci, G., Dolman, A. J., Schulze, E. D., Rebmann, C., Moors, E. J., Granier, A., Gross, P., Jensen, N. O., Pilegaard, K., Lindroth, A., Grelle, A., Bernhofer, C., Grünwald,

10 T., Aubinet, M., Ceulemans, R., Kowalski, A. S., Vesala, T., Rannik, U., Berbigier, P., Loustau, D., Guemundsson, J., Thorgeirsson, H., Ibrom, A., Minerbi, S., and Jarvis, P.: Respiration as the main determinant of carbon balance in European forests, Nature, 404, 861-865, 2000.

van Gorsel, E., Leuning, R., Cleugh, H. A., Keith, H., and Suni, T.: Nocturnal carbon efflux: reconciliation of eddy covariance and chamber measurements using an alternative to the

$15 \quad u_{*}$-threshold filtering technique, Tellus, 59B, 397-403, 2007.

van Gorsel, E., Leuning, R., Cleugh, H.A., Keith, H., Kirschbaum, M. U. F., and Suni, T.: Application of an alternative method to derive reliable estimates of nighttime respiration from eddy covariance measurements in moderately complex topography, Agric. For. Meteorol., 148, 1174-1180, 2008.

20 van Gorsel, E., Delpierre, N., Leuning, R., Black, A., Munger, J. W., Wofsy, S., Aubinet, A., Feigenwinter, C., Beringer, J., Bonal, D., Chen, B., Chen, J., Clement, R., Davis, K. J., Desai, A. R., Dragoni, D., Etzold, S., Grünwald, T., Gu, L., Heinesch, B., Hutyra, L. R., Jans, W. W. P., Kutsch, W., Law, B. E., Leclerc, M. Y., Mammarella, I., Montagnani, Y., Noormets, A., Rebmann, C., and Wharton, S.: Estimating nocturnal ecosystem respiration from the vertical turbulent flux and change in storage of $\mathrm{CO}_{2}$, Agric. For. Meteorol., 149, 1919-1930, 2009.

Webb, E., Pearman, K., and Leuning, R.: Correction of flux measurement for density effects due to heat and water vapor transfer, Q. J. Roy. Meteorol. Soc., 106, 85-100, 1980.

Wofsy, S. C., Goulden, M. L., Munger, J. W., Fan, S. M., Bakwin, P. S., Daube, B. C., Bassow, S. L., and Bazzaz, F. A.: Net exchange of $\mathrm{CO}_{2}$ in a mid-latitude forest, Science, 260, 13141317, 1993.

Wohlfahrt, G., Bahn, M., Haslwanter, A., Newesely, C., and Cernusca, A.: Estimation of daytime respiration to determine gross production of a mountain meadow, Agric. For. Meteorol., 130, 13-25, 2005.

BGD

$7,1201-1232,2010$

\section{Estimation of nighttime ecosystem respiration}

M. S. Hossen et al.

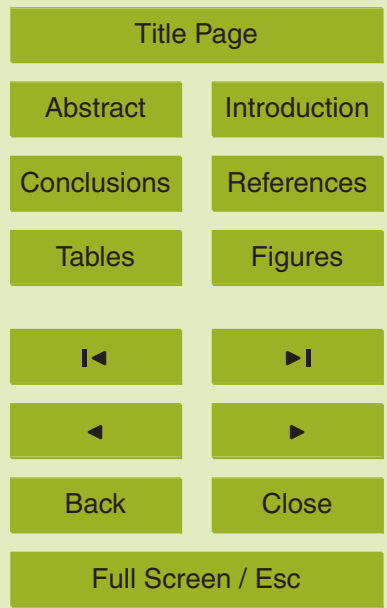

Printer-friendly Version

Interactive Discussion 
Xu, L. and Baldocchi, D. D.: Seasonal variation in carbon dioxide exchange over a Mediterranean annual grassland in California, Agric. For. Meteorol., 123, 79-96, 2004.

Yatagai, A. Arakawa, O., Kamiguchi, K., Kawamoto, H., Nodzu, M. I., and Hamada, A.: A 44year daily gridded precipitation dataset for Asia based on a dense network of rain gauges,

5 SOLA, 5, 137-140, 2009.

Zhu, Y. L., Wu, J. S., and Zhou, W. J.: $\mathrm{CO}_{2}$ emission from the paddy ecosystem in subtropical region and its influence factors, China Environ. Sci., 25, 151-154, 2005 (in Chinese with English abstract).

Zhu, Z., Sun, X., Wen, X., Zhou, Y., Tian, J., and Yuan, G.: Study on the processing method of nighttime $\mathrm{CO}_{2}$ eddy covariance flux data in ChinaFLUX, Sci. in China Series D: Earth Sci., 49, 36-46, 2006.

Zou, J. W., Huang, Y., and Zong, L. G., Zheng, X. H., and Wang, Y. S.: A field study on $\mathrm{CO}_{2}$, $\mathrm{CH}_{4}$, and $\mathrm{N}_{2} \mathrm{O}$ emissions from rice paddy and impact factors, Acta Scientiae Circumstantiae, 23, 758-764, 2003 (in Chinese with English abstract).

\section{BGD}

$7,1201-1232,2010$

\section{Estimation of nighttime ecosystem respiration}

M. S. Hossen et al.

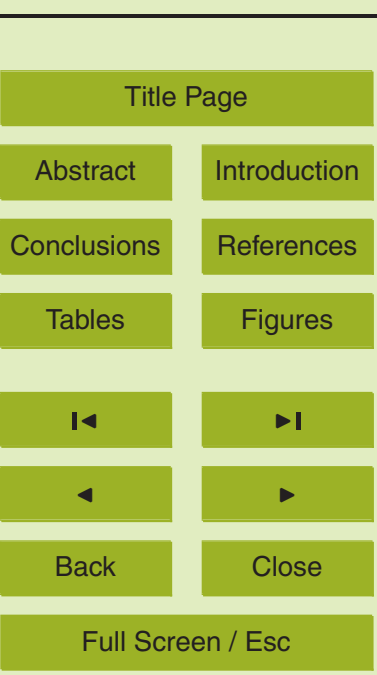

Printer-friendly Version

Interactive Discussion 
BGD

Table 1. Parameters $a$ and $b$ and the coefficient of determination $r^{2}$ of the fitted regression functions between nighttime ecosystem respiration $R_{\mathrm{e}}$ and air temperature $T$ by different approaches and periods. The regression equation used for flux calculation.

\begin{tabular}{lccc}
\hline Periods & Parameter & General method & Alternate method \\
\hline & $a$ & 1.1884 & 1.7154 \\
Total growing DOY (165-290) & $b$ & 0.0393 & 0.0254 \\
& $r^{2}$ & 0.8911 & 0.7099 \\
Early vegetation DOY (165-190) & $a$ & 0.5171 & 0.6783 \\
& $b$ & 0.0518 & 0.0446 \\
& $r^{2}$ & 0.5724 & 0.3953 \\
Mid vegetation DOY (191-220) & $a$ & 3.814 & 4.7236 \\
& $b$ & 0.0071 & -0.0048 \\
& $r^{2}$ & 0.0141 & 0.0043 \\
Full vegetation DOY (221-238) & $a$ & 2.525 & 2.5082 \\
& $b$ & 0.0243 & 0.0246 \\
& $r^{2}$ & 0.6163 & 0.4971 \\
Mature \& harvest DOY (268-280) & $a$ & 1.0352 & 2.0829 \\
& $b$ & 0.0404 & 0.0083 \\
& $r^{2}$ & 0.8452 & 0.2217 \\
\hline
\end{tabular}

7, 1201-1232, 2010 nighttime ecosystem respiration

M. S. Hossen et al.

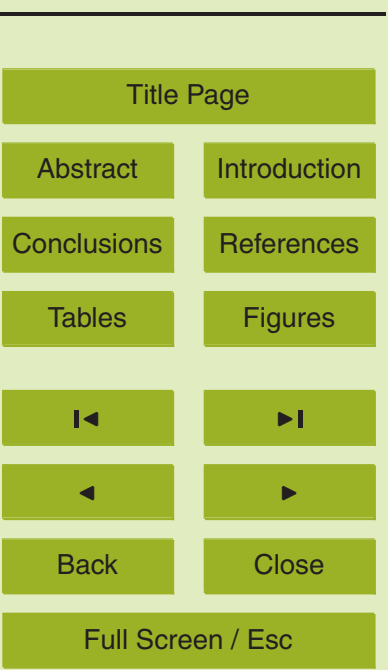

The fitted functions are of exponential form: $R_{\mathrm{e}}=a \exp (b T)$. 


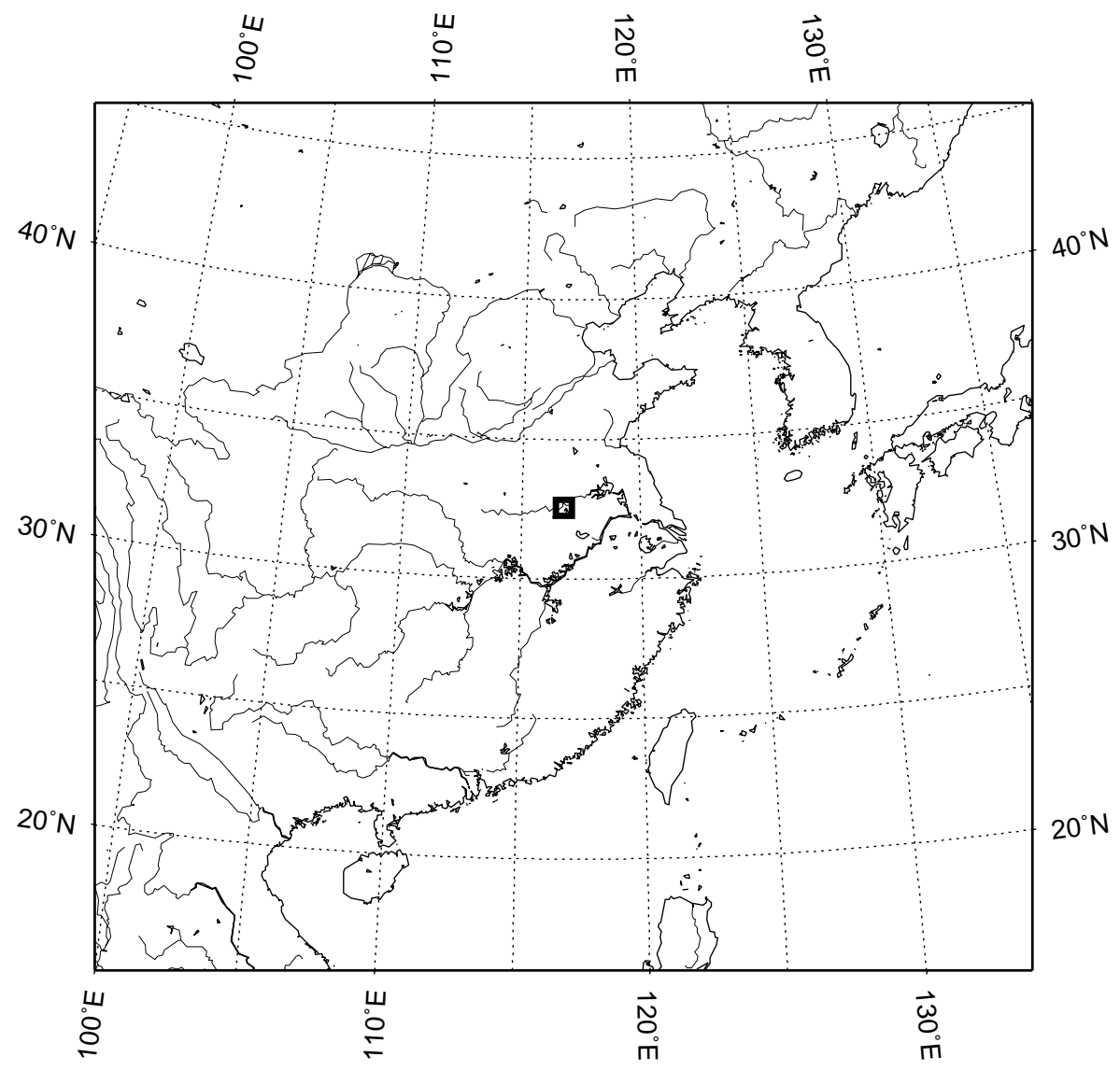

Fig. 1. Location of the study site in Shouxian $\left(32.55^{\circ} \mathrm{N}, 116.78^{\circ} \mathrm{E}, 22.7 \mathrm{~m}\right.$ a.s.I.), near the Huai River in Anhui Province, China. The study site is indicated by a black mark (घ).
BGD

$7,1201-1232,2010$

\section{Estimation of nighttime ecosystem respiration}

M. S. Hossen et al.

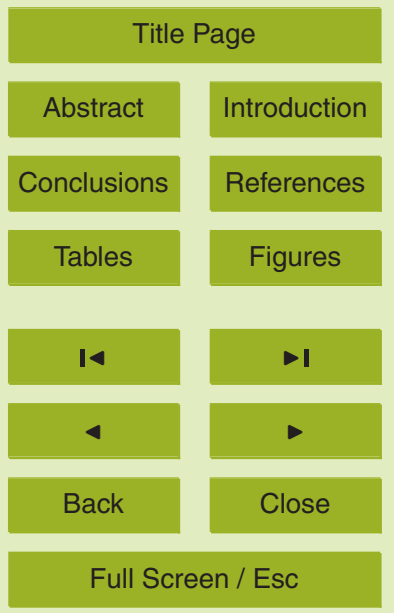

Printer-friendly Version

Interactive Discussion 


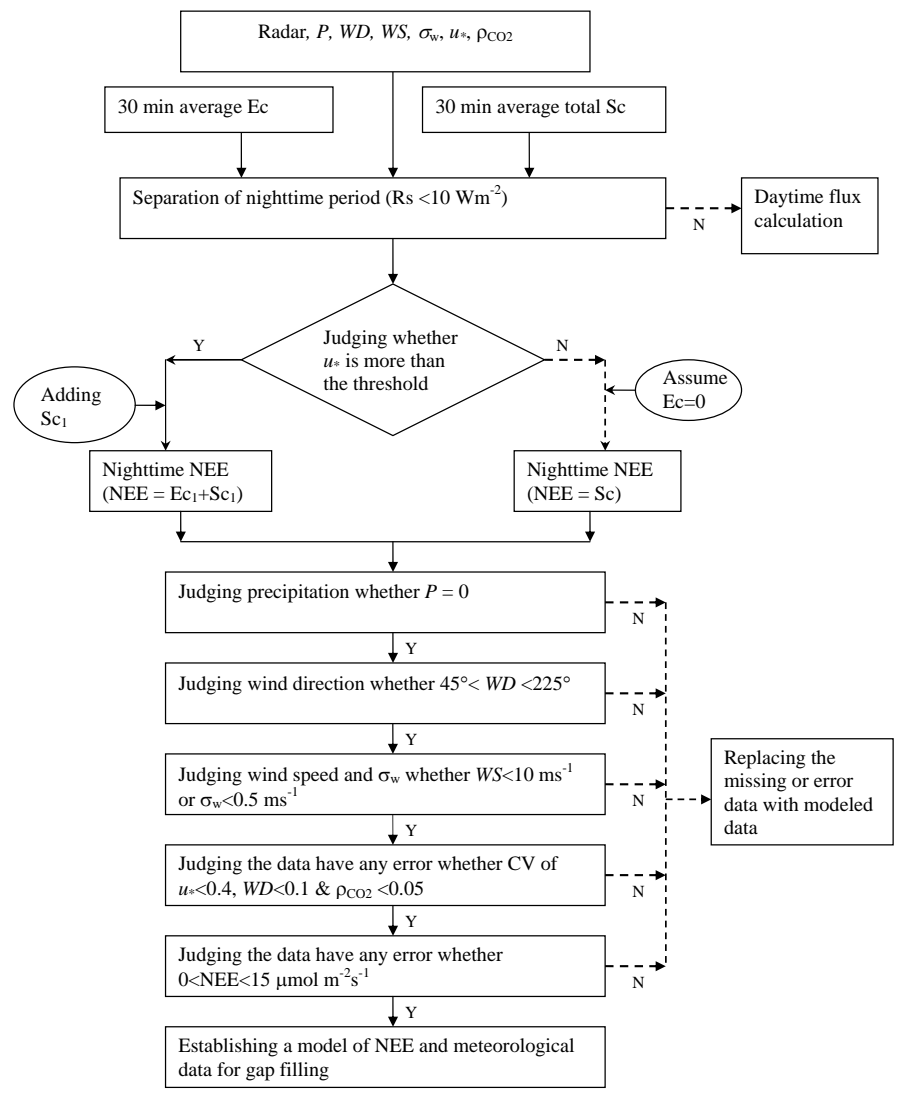

BGD

$7,1201-1232,2010$

\section{Estimation of nighttime ecosystem respiration}

M. S. Hossen et al.

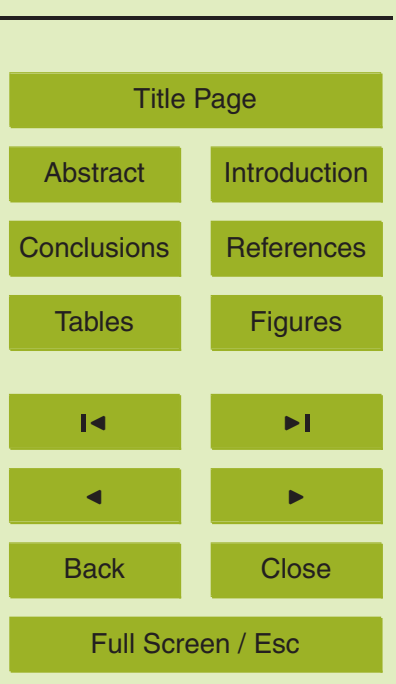

Fig. 2. Flowchart for nighttime $\mathrm{CO}_{2}$ processing at the paddy field site. $R_{\mathrm{s}}$ : solar radiation, $u_{*}$ :

Printer-friendly Version friction velocity, NEE: nighttime net ecosystem exchange, Ec: eddy flux, Sc: integrated storage change, $\mathrm{Sc}_{1}$ : $3.5 \mathrm{~m}$ height storage change, $\mathrm{P}$ : precipitation, WD: wind direction, WS: wind Interactive Discussion speed, $\sigma_{w}$ : turbulent intensity, $\rho_{\mathrm{CO} 2}: \mathrm{CO}_{2}$ density, and $\mathrm{CV}$ : coefficient of variation. 

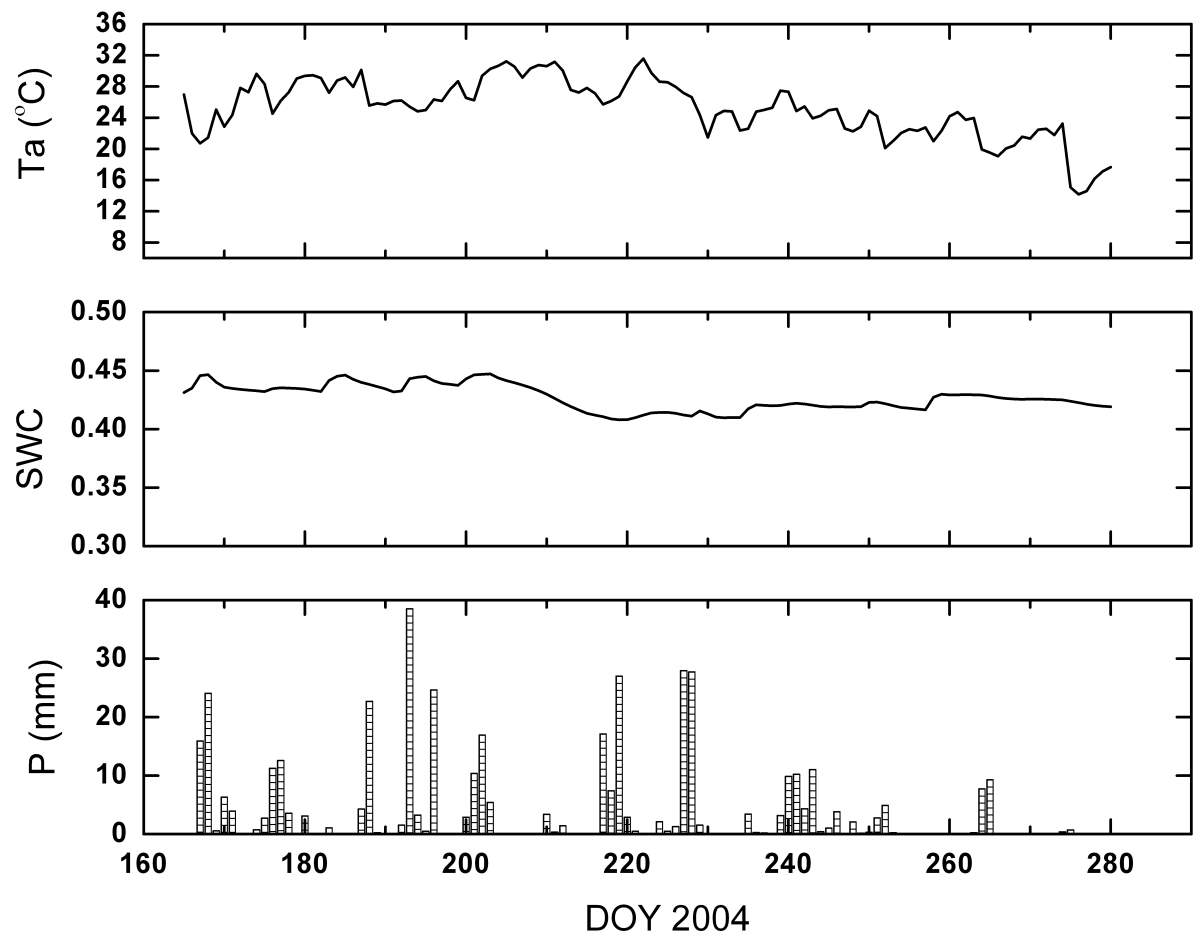

Fig. 3. Seasonal courses of meteorological variables at the rice paddy field site in Shouxian during the 2004 growing period. Ta: daily mean air temperature, SWC: daily mean soil water content, and P: daily precipitation.
BGD

$7,1201-1232,2010$

Estimation of nighttime ecosystem respiration

M. S. Hossen et al.

\section{Title Page}

Abstract

Introduction

Conclusions

References

Tables

Figures

14

$>$ I

4

Back

Close

\section{Full Screen / Esc}

Printer-friendly Version

Interactive Discussion 


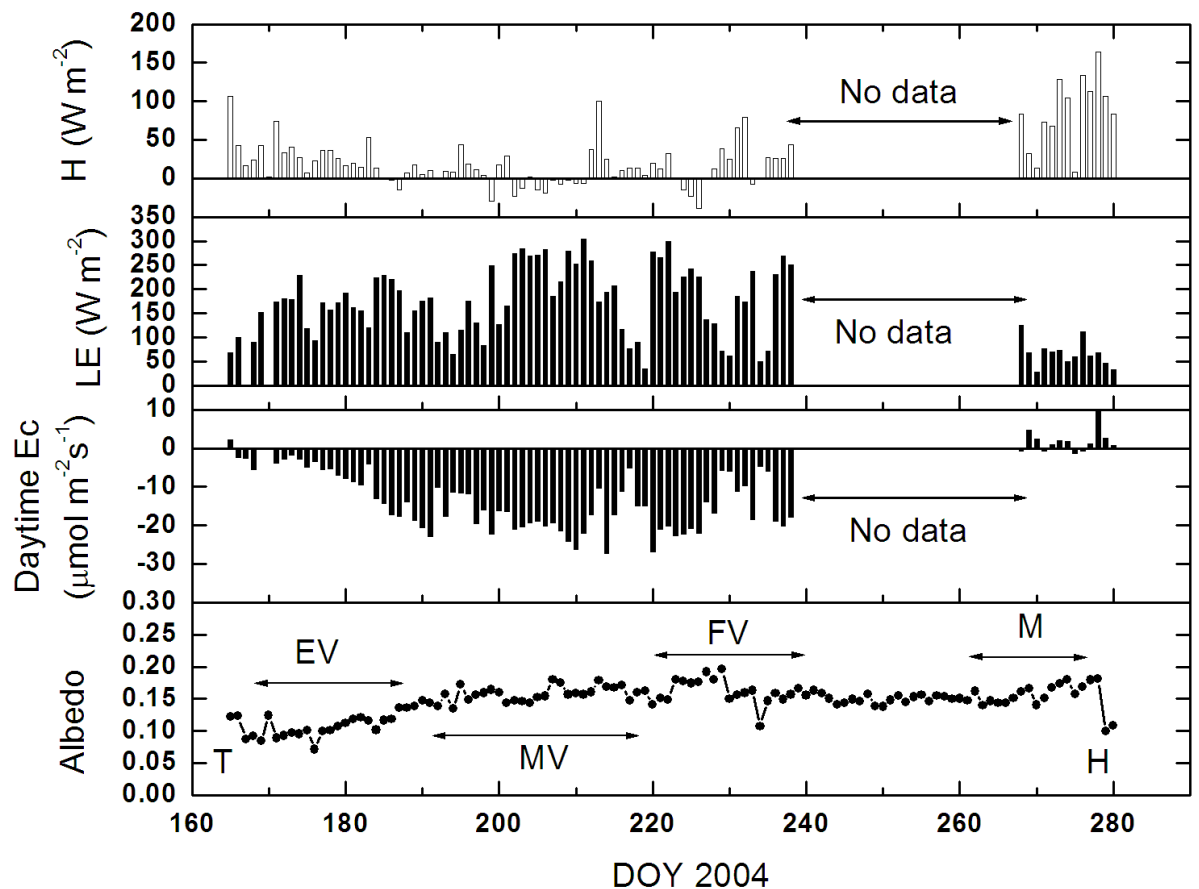

Fig. 4. Seasonal variations in sensible heat $(H)$, latent heat (LE), and daytime $\mathrm{CO}_{2}$ (Ec) fluxes averaged between 08:00 and 16:00 Beijing Standard Time (BST), and surface albedo averaged between 11:00 and 13:00 BST (T, EV, MV, FV, M, and $\mathrm{H}$ represent the rice transplanting, early vegetation, mid-vegetation, full vegetation, mature, and harvest periods, respectively).
BGD

$7,1201-1232,2010$

Estimation of nighttime ecosystem respiration

M. S. Hossen et al.

\section{Title Page}

Abstract

Introduction

Conclusions

References

Tables

Figures

14

$\rightarrow$

4

Back

Close

\section{Full Screen / Esc}

Printer-friendly Version

Interactive Discussion 
BGD
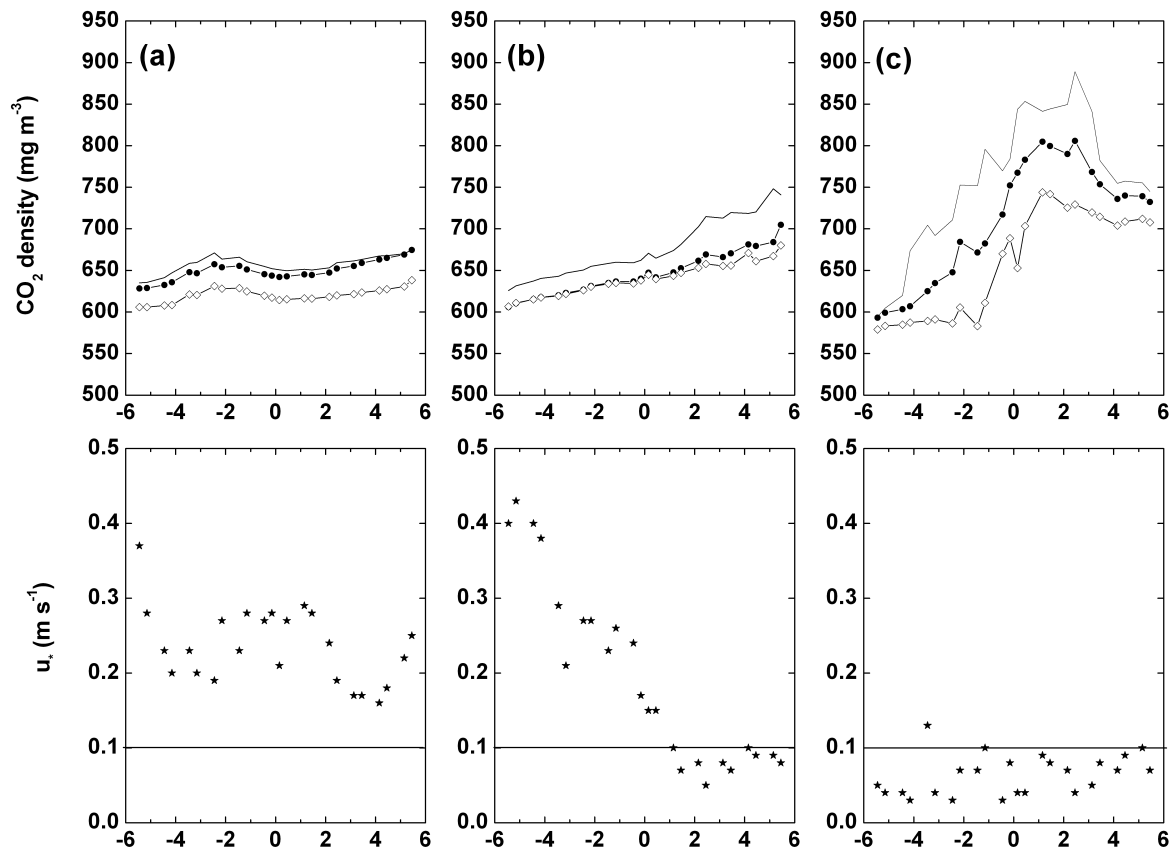

Time (h, 2004/08/11 00:00 LT=0)

0) Time (h, 2004/07/23 00:00 LT=0)

Title Page

Abstract

Conclusions

Tables

14

4

Back

Fig. 5. Nighttime $\mathrm{CO}_{2}$ density and friction velocity $\left(u_{*}\right)$ for (a) windy, (b) intermittent, and (c) calm nights; the symbols represent the following:,$- 3.5 \mathrm{~m}$ height; $\bullet, 12.2 \mathrm{~m}$ height, and $\diamond, 32 \mathrm{~m}$ height.

$7,1201-1232,2010$

\section{Estimation of nighttime ecosystem respiration}

M. S. Hossen et al.

Introduction

References

Figures

$\rightarrow 1$

Close

\section{Full Screen / Esc}

Printer-friendly Version

Interactive Discussion 


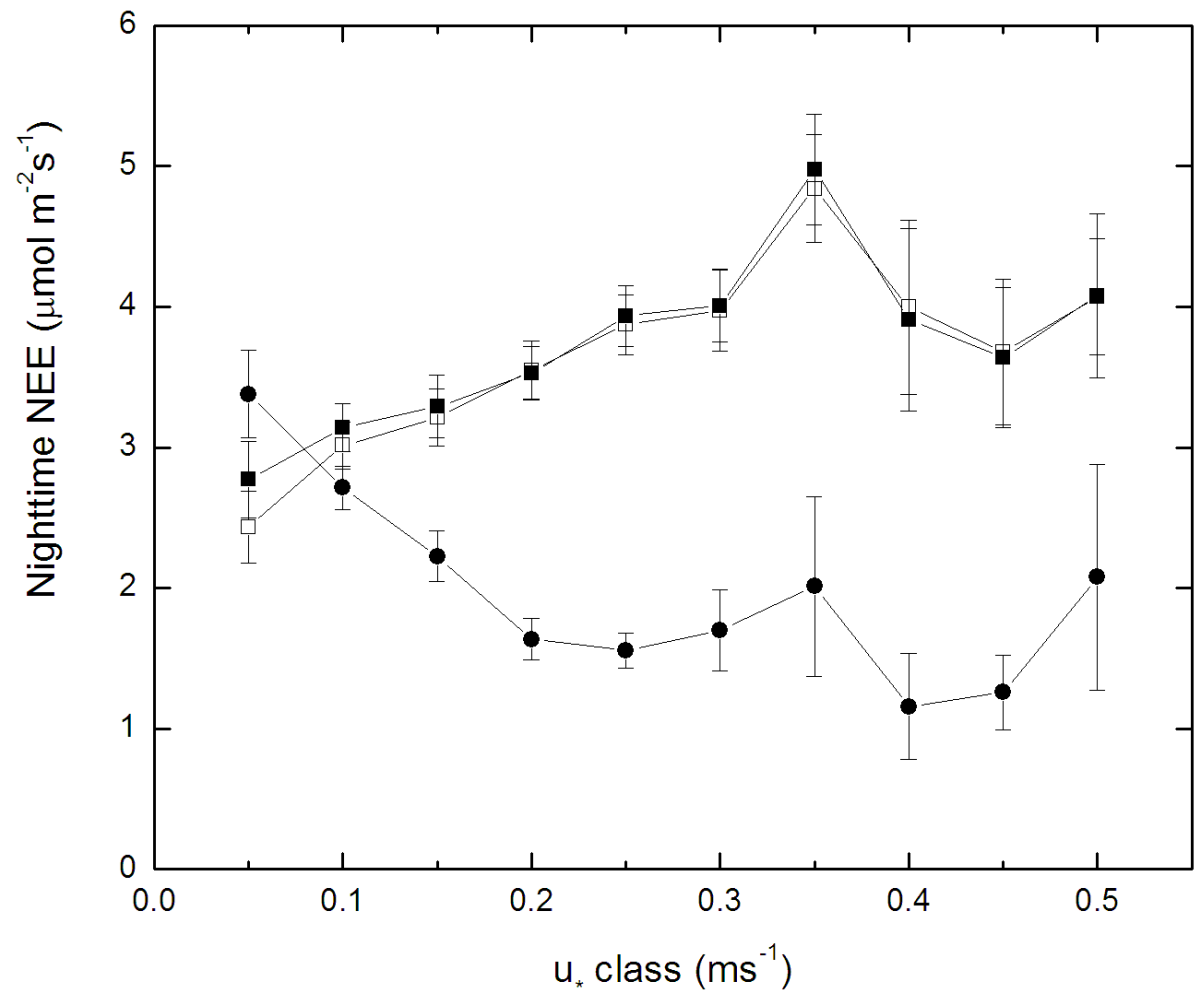

7, 1201-1232, 2010

\section{Estimation of nighttime ecosystem respiration}

M. S. Hossen et al.

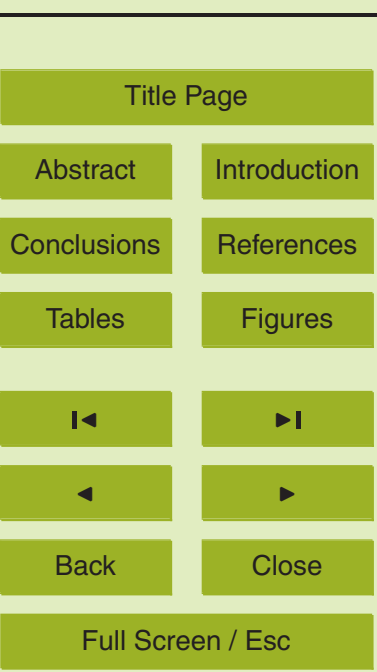

Fig. 6. Nighttime NEE, eddy flux, and storage change as a function of friction velocity $\left(u_{*}\right)$ class; the symbols represent the following: $\mathbf{\square}$, nighttime $\mathrm{NEE}_{\mathrm{Ec}_{\mathrm{c}}} ; \square$, nighttime $\mathrm{Ec}$; and $\bullet$, nighttime $\mathrm{NEE}_{\mathrm{SC}}$. Vertical bars indicate their standard errors. 


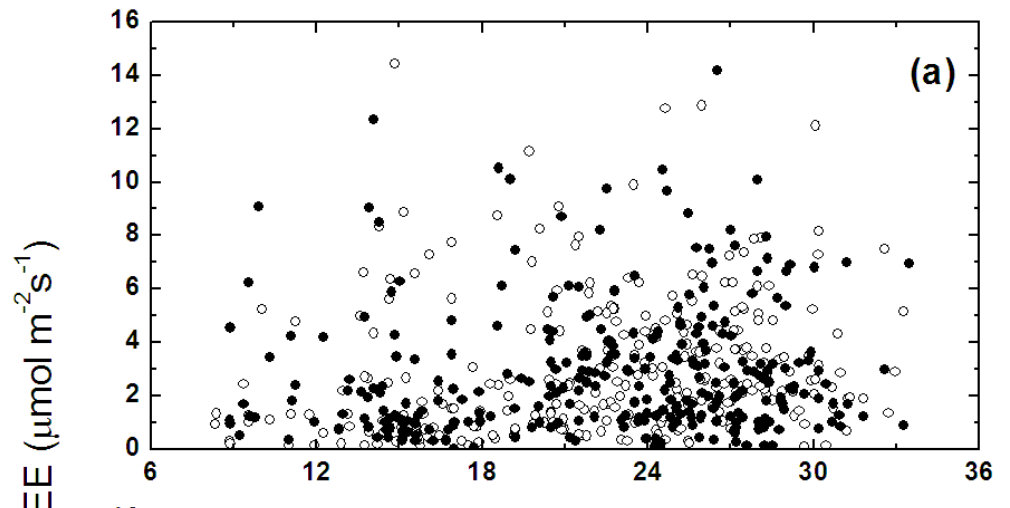

\section{BGD}

7, 1201-1232, 2010

\section{Estimation of nighttime ecosystem respiration}

M. S. Hossen et al.

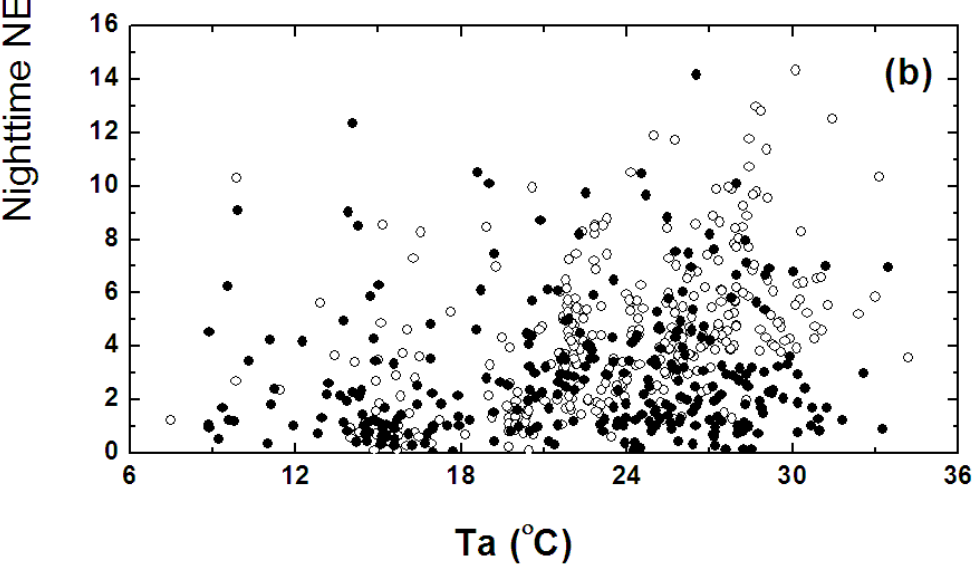

Title Page

Abstract

Introduction

Conclusions

References

Tables

Figures

14

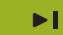

4

Back

Close

\section{Full Screen / Esc}

Printer-friendly Version $\mathrm{NEE}_{\mathrm{SC}}(\circ)$ under low turbulence conditions, and (b) windy condition $\mathrm{NEE}_{\mathrm{Ec}}(\mathrm{o})$ and calm condition $\mathrm{NEE}_{\mathrm{EC}}(\bullet)$.

Interactive Discussion 


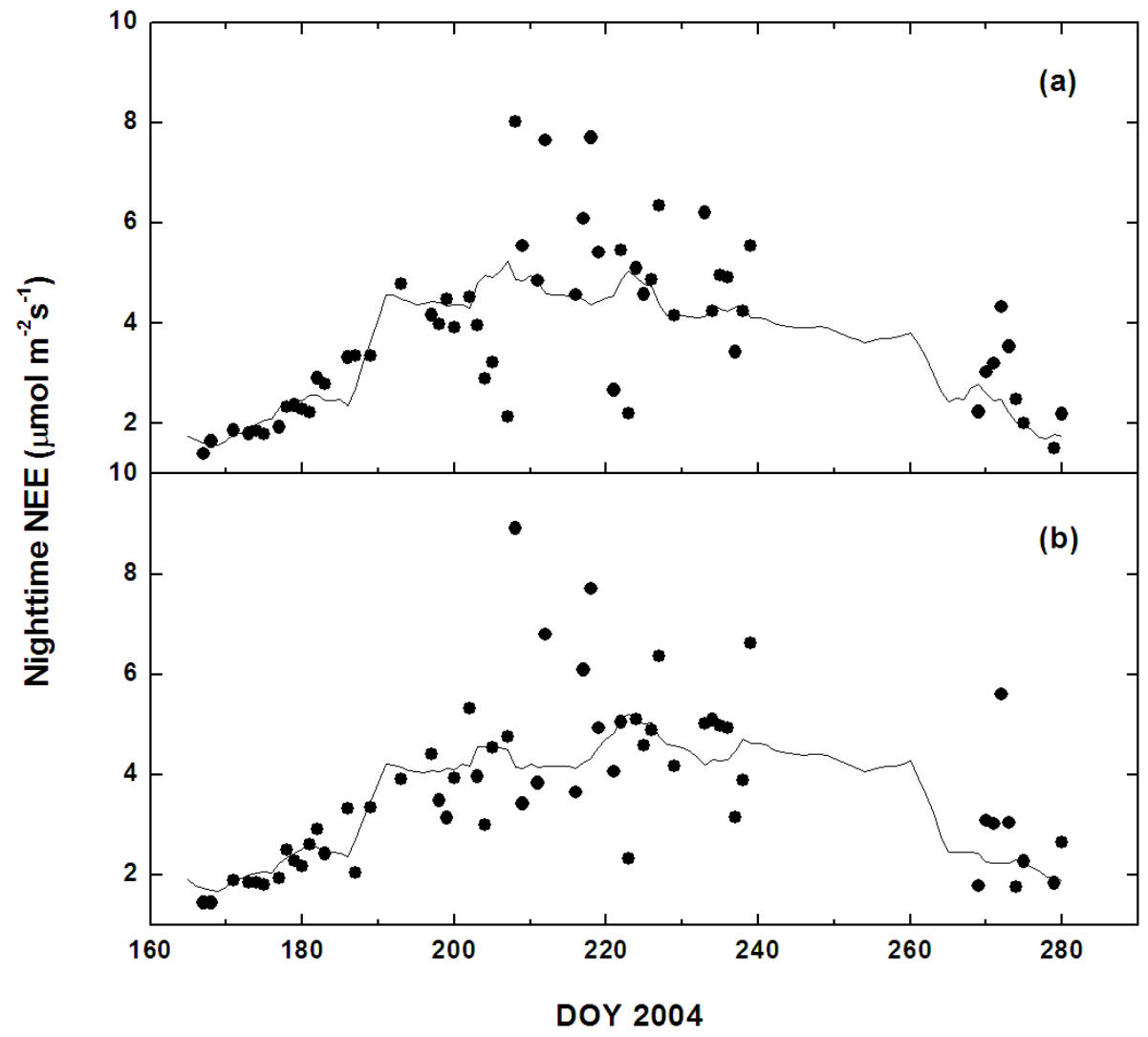

Fig. 8. Seasonal variation in average nighttime $N E E$. (a) $N E E_{E c}$ under both windy and calm conditions, and (b) $\mathrm{NEE}_{\mathrm{Ec}}$ under windy conditions and $\mathrm{NEE}_{\mathrm{Sc}}$ under calm conditions. Five-day running mean gap-filled data $(-)$ and non-gap-filled data $(\bullet)$.

\section{BGD}

7, 1201-1232, 2010

Estimation of nighttime ecosystem respiration

M. S. Hossen et al.

\section{Title Page}

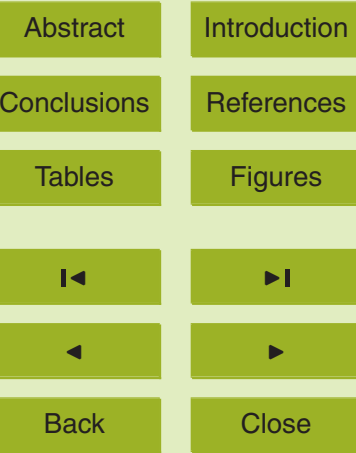

Full Screen / Esc

Printer-friendly Version

Interactive Discussion 


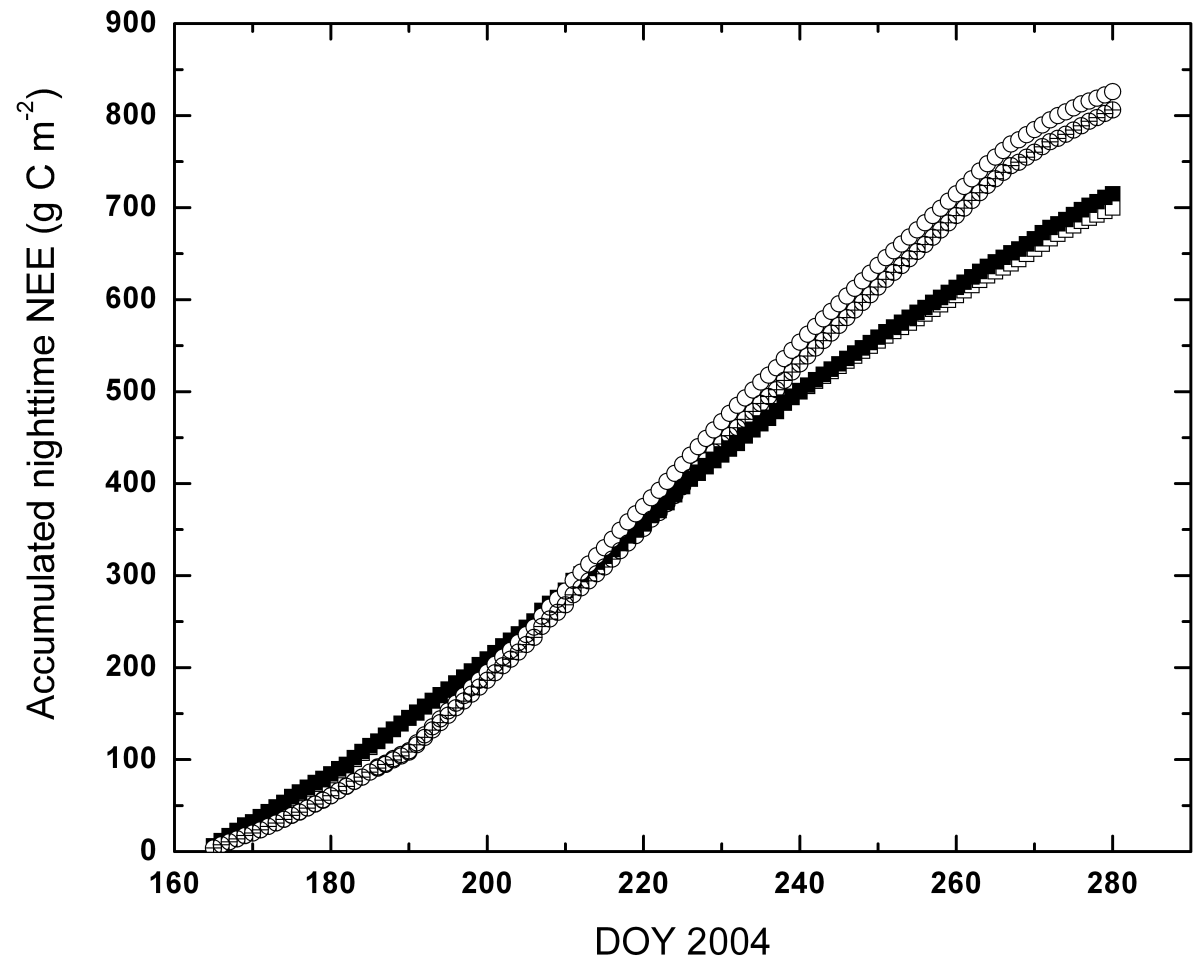

Fig. 9. Example of differences by method for cumulative gap-filled nighttime ecosystem respiration during the investigation period in 2004 (both windy and calm conditions $\mathrm{NEE}_{\mathrm{Ec}}$ with the single exponential function ( $\square$ ), windy condition $\mathrm{NEE}_{\mathrm{Ec}}$ and calm condition $\mathrm{NE}_{\mathrm{Sc}}$ with the single exponential function ( $\mathbf{D})$, both windy and calm conditions $\mathrm{NEE}_{\mathrm{Ec}_{\mathrm{C}}}$ with multiple exponential functions (o), windy condition $\mathrm{NEE}_{\mathrm{Ec}}$ and calm condition $\mathrm{NEE}_{\mathrm{Sc}}$ with multiple exponential functions $(\oplus)$.

\section{BGD}

$7,1201-1232,2010$

\section{Estimation of nighttime ecosystem respiration}

M. S. Hossen et al.

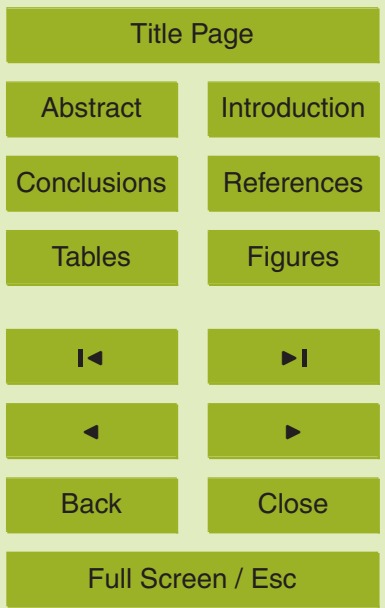

Printer-friendly Version

Interactive Discussion 